\title{
PREHISTORIC ADORNMENTS FROM CUINA TURCULUi
}

MONICA MĂRGĂRIT, ADINA BORONEANT,, CLIVE BONSALL

\begin{abstract}
:
In this study we examine in detail the prehistoric personal adornments from Cuina Turcului rockshelter (Mehedinți County, Romania). Early Mesolithic ("Epipalaeolithic") and Early Neolithic assemblages are compared from the perspectives of context, typology and use-wear. Ornaments from the "Epipalaeolithic" horizons include shells of freshwater gastropods (Lithoglyphus naticoides, Lithoglyphus apertus, Theodoxus danubialis), marine gastropods (Tritia sp.) and scaphopods. Mammalian teeth (Cervus elaphus, Sus scrofa, Canis lupus, Castor fiber, etc.) were perforated. Pendants were obtained by perforating fish vertebrae, as well as segments of mammalian bone and antler. During the Early Neolithic, the shells of Lithoglyphus naticoides and Theodoxus danubialis continued to be used along with scaphopod (tusk) shells. The inventory also includes a marine gastropod, Columbella sp., known from Mesolithic and Early Neolithic contexts elsewhere in the Iron Gates. The presence of a single perforated fox canine suggests that mammalian teeth continued to be turned into pendants. However, new forms of adornment appeared, including cylindrical and disc beads made of various materials, bone buttons and stone decorative elements. These involved more complex technological schemes for processing raw materials. The finds from Cuina Turcului provide evidence for the continuation within the Iron Gates region of Mesolithic ornamental traditions into the Early Neolithic alongside the appearance of new "Neolithic" types, consistent with the arrival and integration into the region of a new population with different cultural traditions.
\end{abstract}

\section{Rezumat: PodoAbele PReistorice de la Cuina Turcului}

În acest studiu, examinăm în detaliu podoabele preistorice din adăpostul de sub stâncă de la Cuina Turcului (județul Mehedinți, România), piesele atribuite mezoliticului timpuriu („epipaleoliticului”) și neoliticului timpuriu fiind comparate din perspectiva contextului, tipologiei şi uzurii. Ornamentele din nivelurile „epipaleolitice” includ cochilii de gasteropode de apă dulce (Lithoglyphus naticoides, Lithoglyphus apertus, Theodoxus danubialis), de gasteropode marine (Tritia sp.) și de scafopode. Acestora li se adaugă dinți de mamifere (Cervus elaphus, Sus scrofa, Canis lupus, Castor fiber, etc.) perforați. Pandantivele au fost obținute prin perforarea vertebrelor de pește, precum și a unor fragmente de os și corn de cervide. Pe durata neoliticului timpuriu, cochiliile de Lithoglyphus naticoides și Theodoxus danubialis au continuat să fie utilizate împreună cu cochiliile de scafopode. Inventarul include, de asemenea, un gasteropod marin, Columbella sp., cunoscut din alte contexte mezolitice și neolitice timpurii în afara regiunii Porțile de Fier. Prezența unui singur canin perforat de vulpe sugerează că dinții de mamifere au continuat să fie transformați în pandantive. $\mathrm{Cu}$ toate acestea, au apărut noi tipuri de podoabă, inclusiv mărgelele cilindrice și discoidale realizate din diverse materiale, nasturi de os și elemente decorative din piatră. Acestea implicau scheme tehnologice mai complexe de prelucrare a materiilor prime. Descoperirile de la Cuina Turcului oferă dovezi privind continuarea utilizării în regiunea Porţilor de Fier, a tradițiilor ornamentale mezolitice pe durata neoliticului timpuriu, alături de apariţia de noi tipuri „neolitice”, concomitent cu sosirea și integrarea în regiune a unei noi populații cu tradiții culturale diferite.

KEYWORDS: Iron Gates, Mesolithic, Early Neolithic, personal adornments, technical transformational scheme, usewear marks.

CUVINTE CHEIE: Porțile de Fier, mezolitic, neolitic timpuriu, podoabe, schema tehnologică de transformare, stigmate de uzură. 


\section{Introduction}

Cuina Turcului $\left(44^{\circ} 35^{\prime} 30^{\prime \prime} \mathrm{N}, 22^{\circ} 15^{\prime} 33^{\prime \prime} \mathrm{E}\right)$, a rockshelter site on the left bank of the Danube ca $32 \mathrm{~km}$ downriver from Lepenski Vir, is one of a series of cave and open-air sites situated in the narrow, canyon-like section of the Iron Gates Gorge known as The Cauldrons. The rockshelter was investigated between 1964 and 1969. Twenty trenches with a combined area of ca $240 \mathrm{~m}^{2}$ were excavated; the trenches were assigned either a single- or 3-letter abbreviation followed by a number (Latin or Arabic) or letter - e.g. S.IV, Cas.D, Int.A(Fig. 1) ${ }^{1}$.

A complex stratigraphic sequence (Fig. 2) was described by the excavators in which three "Epipaleolithic"2 layers or horizons (Epi I, IIa, and IIb) were succeeded by three Early Neolithic (Starčevo-Criș culture) horizons, in turn overlain by deposits belonging to more recent periods (Early Bronze Age, Hallstatt, Medieval).

On present evidence, it is not certain if the "Epipalaeolithic" deposits belong entirely to the Lateglacial period or extend into the Early Holocene. The Epi I horizon was dated by three radiometric ${ }^{14} \mathrm{C}$ measurements on pine charcoal ranging between $12,600 \pm 120 \mathrm{BP}(13,340-12,330 \mathrm{cal} \mathrm{BC})$ and $11,960 \pm 60 \mathrm{BP}(12,060-11,640$ cal $\mathrm{BC})$, while a radiometric date of $10,125 \pm 200 \mathrm{BP}(12,570-9260 \mathrm{cal} \mathrm{BC})$ was obtained on a mixed sample of charcoal and burnt bone fragments from the Epi IIa horizon ${ }^{3}$. Human bones from the Epi II horizon, belonging to two adult individuals, have similar AMS ${ }^{14} \mathrm{C}$ dates (OxA-19203, OxA-19202) and almost identical C- and N-isotope values, the reservoircorrected ages of these samples suggesting a date at the beginning of the Holocene rather than in the Lateglacial.

The dating of the Early Neolithic deposits in the Cuina Turcului rockshelter is equally problematic, and currently rests on seven AMS ${ }^{14} \mathrm{C}$ dates on animal and human bone (Tab. 1). Allowing for uncertainty over diet-derived offsets in the ${ }^{14} \mathrm{C}$ ages of bone samples from two children, both individuals likely date to the period between 6200 and 5800 cal BC which spans the Mesolithic-Neolithic transition in the Iron Gates. The five caprine bone dates are more precise, but are not entirely consistent with the stratigraphic interpretation. The two dates for the "Criş I" horizon (OxA-30446, OxA-30444) are statistically different. Of the three "Criș III" dates, OxA-30443 is older than OxA-30444 from the "Criș I" horizon, while the other two dates (OxA-30445, OxA-30442) fall in the Early Bronze Age. Furthermore, when reviewing original field drawings and finds from the Early Neolithic deposits ${ }^{4}$, stratigraphic anomalies were noted possibly related to disturbances (e.g. pit features) that were not recorded either in the field notes or in subsequent publications.

\section{Cuina Turcului adornments reported in previous publications}

Four main publications make reference to the "Epipaleolithic" excavations and finds at Cuina Turcului ${ }^{5}$ and two to the Early Neolithic finds ${ }^{6}$, while a detailed morpho-functional study of adornments and decorated artefacts was undertaken by the senior author in her $\mathrm{PhD}$ thesis ${ }^{7}$. Objects interpreted as personal adornments were reported from both sets of deposits.

According to Păunescu ${ }^{8}$, only shell, tooth and bone were used for manufacturing adornments during the "Epipaleolithic". Fifteen perforated teeth (red deer canines and wolf, wild boar and ruminant incisors) were reported from the Epi I and II horizons and described as "pendants". The Epi I horizon yielded eight red deer canines, one lower wolf incisor, one wild boar incisor and two ruminant incisors. From the Epi II horizon came three red deer canines ${ }^{9}$, one rectangular bone plate (perforated, with traces of ochre) and two large fish vertebrae (perforated). The Epi I horizon yielded a few tusk ("Dentalium") shell fragments, while from the Epi II horizon were recovered an unspecified number of perforated gastropod shells of Theodoxus transversalis, Theodoxus danubialis, Lithoglyphus naticoides, Tritia neritea and Zebrina detrita) ${ }^{10}$. Apart from T. neritea, the other shells could have been obtained locally along the Danube near the rockshelter, though acquisition through exchange is not excluded.

\footnotetext{
S. = Secțiune (section), Cas. = Casetă (box), Int. = Intermediar (intermediary or connecting trench).

2 In published accounts by different authors, the "Epipaleolithic" horizons were variously described as Azilian, RomanelloAzilian, Romanellian, Clisurean or Tardigravettian (Nicolăescu-Plopşor et al. 1968; Boroneanț 1970; Boroneanț 2000; Păunescu 1970; Păunescu 1978; Păunescu 2000).

3 Păunescu 1970; Păunescu 1978; Păunescu 2000.

4 Boroneanț 2012; Boroneant, Bălășescu 2016.

Păunescu 1970; Păunescu 1978; Păunescu 2000; Boroneanț 2000.

Boroneanț 1970; Păunescu 1978; Boroneanț 2012; Boroneanț, Bălășescu 2016.

Mărgărit 2008.

Păunescu 1970; Păunescu 1978; Păunescu 2000.

Păunescu 2000, 344.

10 Păunescu 1970; Păunescu 1978; Păunescu 2000.
} 

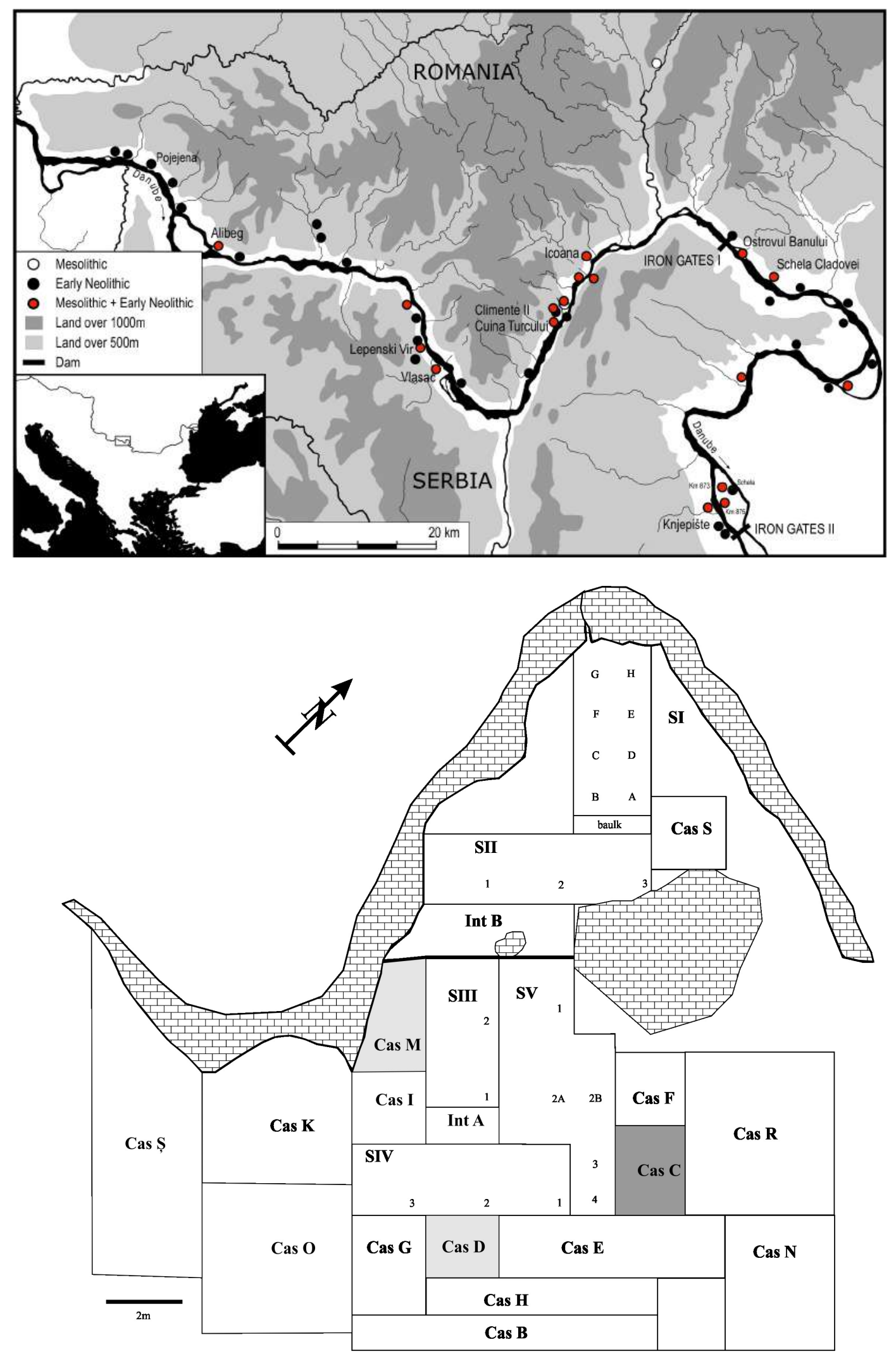

caprine bone samples

human bone samples

section in Figure 2

Figure 1. 1. Mesolithic and Early Neolithic sites in the Iron Gates mentioned in the text; 2. general plan of the Cuina Turcului rockshelter indicating the trenches from which ${ }^{14} \mathrm{C}$ samples were taken. 


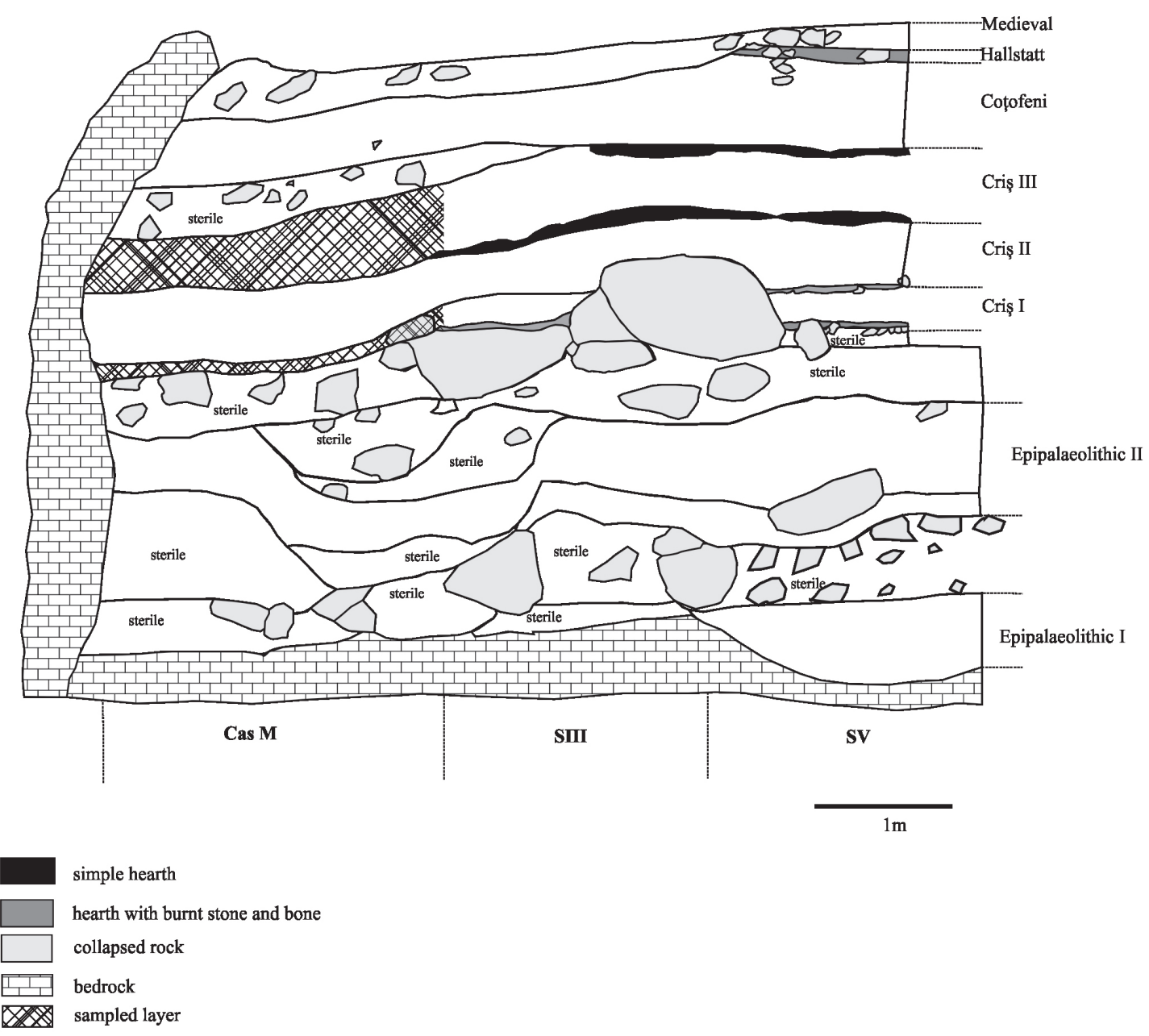

Figure 2. Stratigraphic sequence of trenches S.II, S.III and Cas.M indicating the layers from which ${ }^{14} \mathrm{C}$ samples were taken.

Table 1. ${ }^{14} \mathrm{C}$ dates from the Early Neolithic horizons in the Cuina Turcului rockshelter (after Bonsall, Boroneanț 2018). Calibrated ages are rounded outwards to 10 years.

\begin{tabular}{|c|c|c|c|c|c|c|c|c|}
\hline Lab ID & Sample & Context & Layer & $\begin{array}{c}{ }^{14} \mathrm{C} \text { age } \\
\text { (BP) }\end{array}$ & $\begin{array}{l}\delta^{13} \mathbf{C} \\
(\% 0)\end{array}$ & $\begin{array}{l}{ }^{15} \mathrm{~N} \\
(\%)\end{array}$ & $\mathbf{C} / \mathbf{N}$ & $\begin{array}{c}\text { Calibrated } \\
\text { age range } \\
(95 \%) \text { cal } \\
\text { BC }\end{array}$ \\
\hline OxA-19205 & bone, new-born, rib & $15.1 \mathrm{~T}$ & Criș I & $7650 \pm 36$ & -19.1 & 17.1 & 3.3 & $6210-5780$ \\
\hline OxA-19204 & bone, child $<12$, left tibia & Cas.D, $2.05 \mathrm{~m}$ & Criș III & $7324 \pm 39$ & -19.4 & 13.9 & 3.1 & $5990-5730$ \\
\hline OxA-30446 & bone, acetabulum, caprine & Cas.C, 1. & Criș I & $7075 \pm 39$ & -19.7 & 5.1 & 3.2 & $030-5880$ \\
\hline OxA-30443 & bone, metat & Cas.M & Criș III & $7029 \pm 35$ & -19.6 & 6.6 & 3.3 & $6000-5840$ \\
\hline OxA-30444 & one, metatarsus, caprine & Cas.M & Criș I & $6827 \pm 39$ & -20.0 & 6.9 & 3.3 & $5790-5630$ \\
\hline OxA-30445 & bone, acetabulum, caprine & Cas.M & Criș III & $4727 \pm 33$ & -20.0 & 6.9 & 3.3 & $3640-3370$ \\
\hline OxA-30442 & bone, mandible, caprine & Cas.M, $1.38 \mathrm{~m}$ & Criș III & $4143 \pm 28$ & -20.0 & 6.1 & 3.3 & $2880-2620$ \\
\hline
\end{tabular}


The adornment types identified from the Early Neolithic horizons were pendants (of bone, tooth and stone), beads (of snail and mussel shell, bone, tooth and stone), three bone "buttons", and eight fragments of bone buckles. Of the 14 pendants, four were made of bone, five from teeth (Cervus elaphus, Sus scrofa and Canis sp.) and five of stone. The bone and tooth pendants came from the "Criș I and II" horizons, while stone pendants occurred in all three Criș horizons. The bone pendants were described as "ring-like, quasi-trapezoidal or semicircular" while the stone pendants were "quasi-trapezoidal, cylindrical or circular". One of the stone objects described by Păunescu as a pendant ${ }^{11}$ had a groove on one face rather than a perforation and its status as a body ornament is questionable. There were 73 beads made from shells (mainly Lithoglyphus naticoides, Theodoxus danubialis and Antalis ["Dentalium"'] sp.). Also noted were two perforated Unio shells. Some additional stratigraphic information was provided by Boroneanț ${ }^{12}$ : a ring fragment, a perforated button and a perforated red deer tooth were found in the "Criș I" horizon, while small "circular" (disc) beads (some with traces of a red substance) came from all three Criş horizons and perforated "snail" shells from the "Criș II and III" horizons.

The total number of adornments was never stated for either the "Epipalaeolithic" or the Early Neolithic, and no details were provided of the archaeological contexts of these finds.

\section{Adornments recorded in the field notes}

Three field notebooks (kept by Ștefan Roman, Vasile Boroneanț and Mișu Davidescu, respectively) report on trenches S.II-S.IV of the 1964 excavations and two more (kept by Al. Păunescu) on the trenches excavated in 1965-1969. The personal adornments recorded in these notebooks are listed in Tab. 2.

According to the field documentation, in the "Epipalaeolithic" horizons there were over 24 perforated snail shells, as well as a perforated deer tooth, ,a small bone bead" and a perforated fish vertebra. The Early Neolithic horizons yielded at least 35 perforated snail shells, eight small circular bone beads, four fragments of bone "buckles", two "perforated white stones", one perforated fish vertebra, one fragmentary bone ring, one polished stone bead, one "tubular" stone bead, and a group of 16 "tubular" beads of unspecified material. Also mentioned is a stone fragment polished on one face, though whether this was part of an adornment or a utilitarian tool is uncertain.

\section{The existing collection and the methodology of study}

The collection from Cuina Turcului held at the "Vasile Pârvan" Institute of Archaeology in Bucharest comprises 82 items, 72 from the "Epipalaeolithic" and 10 from the Early Neolithic horizons. No artefacts from the 1964 season are part of the collection.

In both the field notes and subsequent publications ${ }^{13}$ classification of the adornments was based on their presumed function as suggested by their size, shape and means of attachment.

Table 2. Adornments mentioned in the field documentation (types are reported as listed in the field notes).

\begin{tabular}{|r|l|l|l|}
\hline Id. & \multicolumn{1}{|c|}{ Type } & \multicolumn{1}{|c|}{ Period } & \multicolumn{1}{|c|}{$\begin{array}{c}\text { Context (trench, square, depth, } \\
\text { package no.) }\end{array}$} \\
\hline 1 & 11 perforated snail shells & Epi II & S.V, sq.1, 3.88-3.91 m, 352 \\
\hline 2 & 2 perforated snail shells & Epi II & S.IV, sq.2, 3.40-3.50 m, 178 \\
\hline 3 & 2 perforated snail shells & Epi II & S.V, sq.3, 3.73-3.83 m \\
\hline 4 & perforated deer tooth & Epi II & Cas.D, 3.53-3.70 m, 424 \\
\hline 5 & perforated fish vertebra & Epi II & Cas.I, 3.90-4.00 m, 592 \\
\hline 6 & perforated snail shell & Epi II & Int.A, sq.2, 3.00-3.06 m \\
\hline 7 & perforated snail shell & Epi II & S.IV, sq.1, 3.28-3.38 m, 159 \\
\hline 8 & perforated snail shell & Epi II & S.V, sq.1, 3.60-3.72 m, 333 \\
\hline 9 & perforated snail shells & Epi II & Int.A, sq.2, 3.36-3.80 m, 386 \\
\hline 10 & perforated snail shells & Epi II & S.IV, sq.1, 3.75-3.95 m, 189 \\
\hline
\end{tabular}

\footnotetext{
11 Păunescu 1978, 33, Fig. 12 no. 17.

12 Boroneanț 1970.

13 Păunescu 1970; Păunescu 1978; Păunescu 2000; Boroneanț 1970; Boroneanț 2000.
} 


\begin{tabular}{|c|c|c|c|}
\hline 11 & perforated snail shells & Epi II & S.V, sq.3, 3.83-3.95 m, 369 \\
\hline 12 & 2 perforated snail shells & Epi & S.II, sq. $2,2.80 \mathrm{~m}$ \\
\hline 13 & bone bead & Epi & S.II, sq. $1,3.70 \mathrm{~m}$ \\
\hline 14 & perforated snail shell & Epi & S.II, sq. $1,2.80 \mathrm{~m}$ \\
\hline 15 & 16 "tubular" beads, 3 perforated snail shells & Criș III & S.V, sq. $1,1.65-1.80 \mathrm{~m}$ \\
\hline 16 & 2 perforated snail shells & Criș III & Int.A, $1.23-1.36 \mathrm{~m}, 279$ \\
\hline 17 & bone hook fragment & Criș III & S.V, sq.2B, $2.00-2.15 \mathrm{~m}, 280$ \\
\hline 18 & tubular stone bead & Criș III & S.V, sq.1, 1.58-1.63 m, 257 \\
\hline 19 & perforated tubular object of white stone & Criș III & Cas.C, $1.48-1.60 \mathrm{~m}, 351$ \\
\hline 20 & bone bead & Criș III & S.IV, sq.3, 1.18-1.30 m, 39 \\
\hline 21 & bone bead & Criș III & S.V, sq.2B, 2.30-2.46 m, 289 \\
\hline 22 & stone object polished on one side & Criș III & Cas.D, $1.52-1.72 \mathrm{~m}, 401$ \\
\hline 23 & 2 perforated snail shells & Criș II & S.V, sq.3, 2.54-2.70 m, 304 \\
\hline 24 & 4 perforated snail shells & Criş II & S.V, sq.3, 2.40-2.54 m, 295 \\
\hline 25 & 4 perforated snail shells & Criş II & S.V, sq.2B, 2.60-2.73 m, 298 \\
\hline 26 & bone buckle fragment & Criș II & Cas.K, $1.25-1.35 \mathrm{~m}$, \\
\hline 27 & bone buckle fragment & Criş II & S.IV, sq.2, 2.02-2.22 m, 92 \\
\hline 28 & perforated fish vertebra & Criș II & Cas.H, $2.06-2.28 \mathrm{~m}, 510$ \\
\hline 29 & perforated snail shell & Criș II & Cas.E, $2.30-2.46 \mathrm{~m}, 458$ \\
\hline 30 & perforated snail shell & Criş II & Int.A, $1.46-1.57 \mathrm{~m}, 288$ \\
\hline 31 & perforated snail shell & Criș II & Int.A, $1.57-1.75 \mathrm{~m}, 293$ \\
\hline 32 & perforated snail shell & Criş II & S.V, sq. $1,2.00-2.15 \mathrm{~m}, 277$ \\
\hline 33 & perforated snail shell & Criș II & S.V, sq.2A, 2.68-2.80 m, 301 \\
\hline 34 & perforated snail shell & Criș II & S.V, sq.2A, 2.15-2.30 m, 283 \\
\hline 35 & $\begin{array}{l}\text { perforated snail shell, bone bead, bone } \\
\text { buckle fragment }\end{array}$ & Criș II & S.V, sq.2A, $2.30-2.45 \mathrm{~m}, 287$ \\
\hline 36 & bone bead, 3 perforated snail shells & Criş II & S.IV, sq.3, 1.80-1.94 m, 89 \\
\hline 37 & 3 perforated snail shells & Criș I & S.IV, sq.2, 2.48-2.62 m, 126 \\
\hline 38 & 4 perforated snail shells & Criş I & Int.A, 2.72-2.85 m, 324 \\
\hline 39 & bone ring fragment, bone buckle fragment & Criş I & S.V, sq.2B, 2.34-3.56 m, 320 \\
\hline 40 & perforated snail shell & Criş I & S.IV, sq.1, 2.60-2.72 m, 119 \\
\hline 41 & perforated snail shells & Criş I & S.IV, sq.3, 2.40-2.60 m, 150 \\
\hline 42 & perforated white stone artefact & Criş I & Int.A, $2.54-2.72 \mathrm{~m}, 315$ \\
\hline 43 & bone bead & Criş I & Cas.I, $2.30-2.60 \mathrm{~m}, 571$ \\
\hline 44 & bone bead & Criș & S.II, sq.2, $1.90 \mathrm{~m}$ \\
\hline 45 & bone bead & Criș & S.III, sq. $1,1.10 \mathrm{~m}$ \\
\hline 46 & bone bead & Criș & S.III, sq.3, $1.10 \mathrm{~m}$ \\
\hline 47 & bone bead, polished stone bead & Criș & S.II, sq. $2,2.50 \mathrm{~m}$ \\
\hline 48 & bone button & Criș & S.II, sq. $2,1.70 \mathrm{~m}$ \\
\hline 49 & bone button, bone hook fragment & Criș & S.II, sq. $1,1.60 \mathrm{~m}$ \\
\hline 50 & bone hook fragment & Criș & S.II, sq. $1,1.70 \mathrm{~m}$ \\
\hline 51 & perforated tooth & Criș & S.II, sq. $1,1.95 \mathrm{~m}$ \\
\hline 52 & perforated tooth & Criș & S.II, sq.2, $1.90 \mathrm{~m}$ \\
\hline 53 & bone bead & Criș & S.IV, sq.E, $0.95 \mathrm{~m}$ \\
\hline
\end{tabular}


The aim of the present study is to review the function of the various types of adornment (based on morphology and use-wear) and to identify (where possible) the operational chains employed in their manufacture. Macroscopic and microscopic examination of the manufacturing and wear traces present on the adornments was undertaken. The location and character of manufacturing and use-wear marks were systematically recorded. Microscopic examination and photography were undertaken with a Keyence VHX-600 digital microscope at magnifications of $\times 30$ to $\times 150$. The analytical criteria for the technological and functional interpretations were established by reference to recent publications on the use of body ornaments in prehistoric contexts ${ }^{14}$; hence our typological classifications sometimes differ from those given in previous publications on Cuina Turcului.

\section{Adornments from the "Epipalaeolithic" horizons}

Perforated gastropod shells from the "Epipalaeolithic" at Cuina Turcului in the collection of "Vasile Pârvan" Institute of Archaeology comprise marine (Tritia sp.), freshwater (Lithoglyphus naticoides, Lithoglyphus apertus, Theodoxus danubialis) and terrestrial (Zebrina detrita) taxa and, apparently, were all found in non-funerary contexts.

There are 37 shells of Lithoglyphus naticoides (Fig. 3.1). The choice of perforation placement depended on the system of attachment and the shell morphology. Regardless of how they were meant to be worn on the body, the thread went through two openings: the natural aperture of the shell and an artificial perforation. In most gastropod shell adornment forms identified from prehistory, the perforation is located on the last (body) whorl. The shells from Cuina Turcului are no exception. This location had certain advantages: it is the largest area of the shell, facilitating the perforation procedure, and being opposite to the aperture allows the thread to pass through both openings.

Obtaining a regular perforation is indicative of good control of the pressure exerted on the wall of the shell and close familiarity with the shell's mechanical properties. Since the form and dimensions of the perforation are fairly consistent, it can be assumed they were made by the same technique. The characteristic elements are the subcircular hole which sometimes is slightly irregular, perforation edges with a "chipped" (faceted) appearance, and cracks at the points of impact (Fig. 3.2). Experiments indicate that indirect percussion was the technique invariably used to create the perforation ${ }^{15}$.

The stability of the perforation, which has to withstand different pressures (rubbing against a thread, body movements, or impact with other elements in beaded ornaments), also has to be considered. The perforation was made at 7.50-8.30 $\mathrm{mm}$ from the aperture. This is more or less the maximum distance from the aperture for the placement of the perforation, given that it was initiated from the interior. The position was not chosen randomly; it has been shown in our experiments that where the perforation was located less than $4 \mathrm{~mm}$ from the aperture the beads fractured within the first three months of use ${ }^{16}$.

Thread wear and bead-on-bead contact where several shells are strung together can leave different marks. The perforation is often deformed at various points from the pressure exerted by the thread. The direction of the deformation can indicate the type of suspension affecting how the thread passed through the perforation and the aperture. Not infrequently, the shell acquires areas of "lustre" caused by rubbing against the skin or a garment. On the specimens from Cuina Turcului we identified two different areas of use-wear development. One occurred between the perforation and the aperture edge caused by friction with the thread, the aperture edge having various morphologies - concave, rectangular or fractured - dictated by the intensity of the use-wear (Fig. 3.4-5). The perforation became strongly deformed on the edge nearest the aperture, developing a concavity with a smoothed wall (Fig. 3.3). The second area with use-wear traces developed on the shell body between the perforation and the apex; the surface became smooth with a macroscopic polish (Fig. 3.6-7). In several cases, a small hole was observed below the apex. All these use-wear traces observed on the edge of the perforation, on the outer lip and the parietal wall of the aperture indicate that all the shell beads had been strung on a thread and worn.

In the case of Lithoglyphus apertus (Fig. 3.8), the perforation is located 9.5-9.8 $\mathrm{mm}$ from the aperture and has a diameter of between 3 and $5 \mathrm{~mm}$. As for the technique of perforation, the subcircular (but irregular) shape of the hole with strongly flared walls and a concave profile (Fig. 3.9) indicate circular abrasion of the area resulting in extensive wear of the surface, though the abrasion was not associated with deformation of the perforation (Fig. 3.10-11).

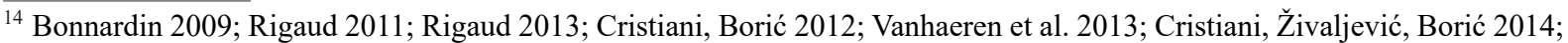
Rigaud, d'Errico, Vanhaeren 2015; Falci et al. 2019; Mărgărit, Dimache 2019.

15 Mărgărit 2016; Lazăr, Mărgărit, Radu 2018; Mărgărit et al. 2018.

${ }^{16}$ Mărgărit 2016.
} 

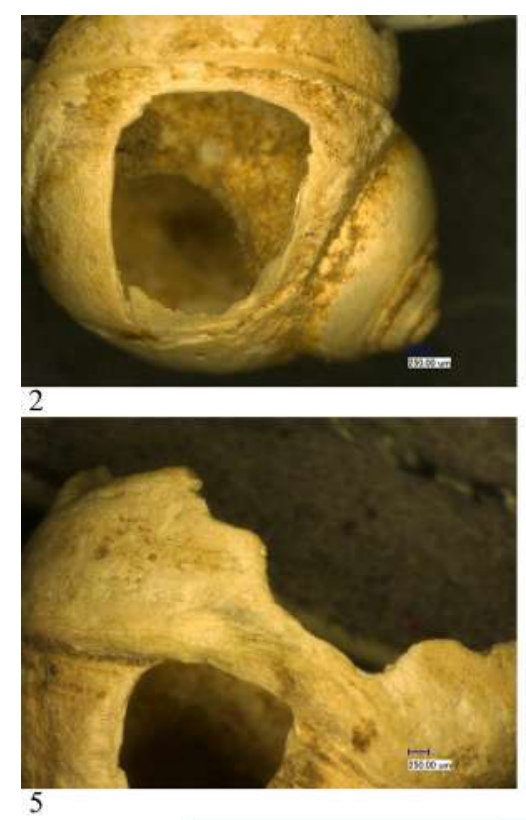
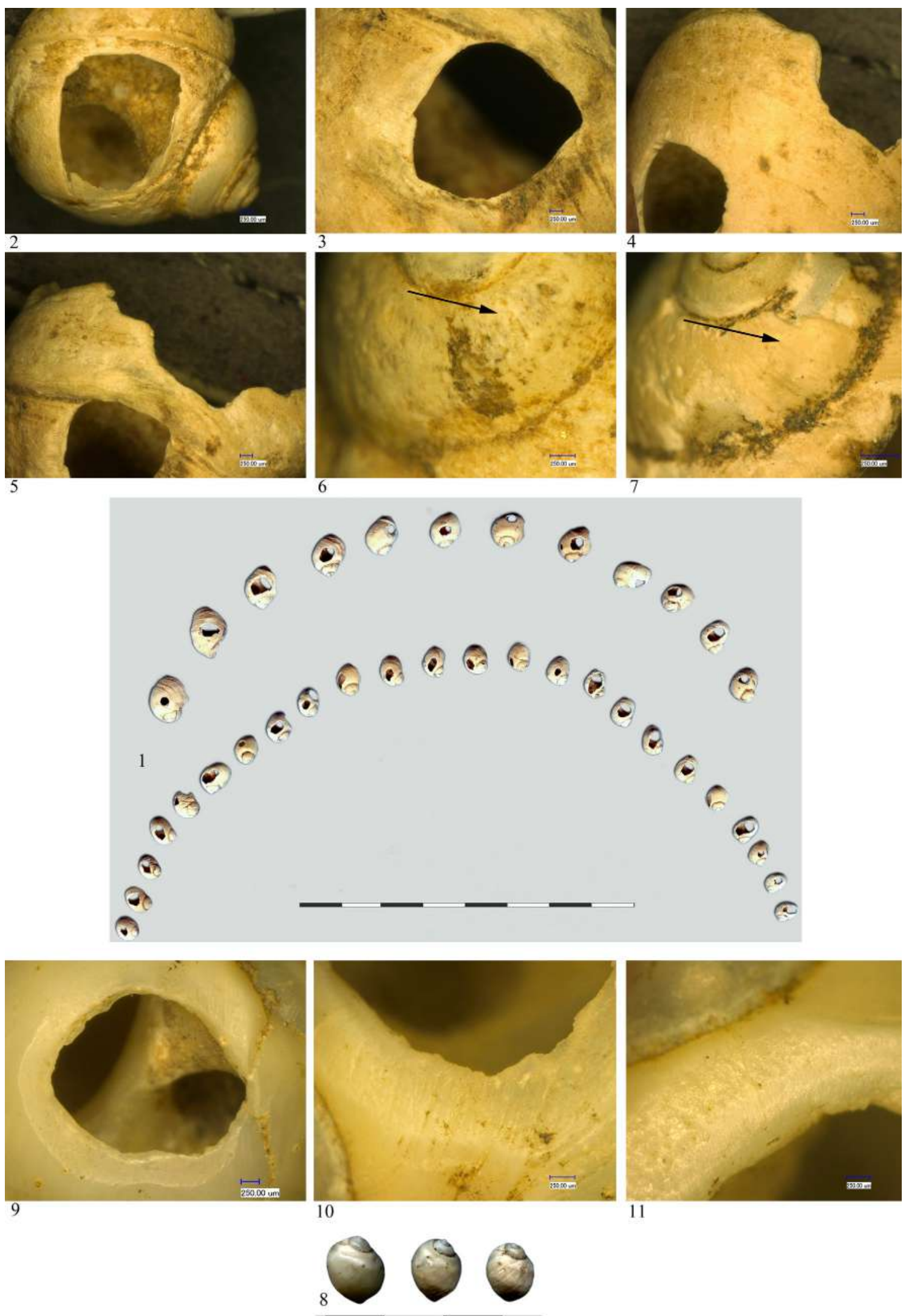

Figure 3. 1 Perforated Lithoglyphus naticoides shells (Mesolithic) $(\mathrm{scale}=1 \mathrm{~cm}) ; 2 .-3$. perforation details $(50 \mathrm{x}, 75 \mathrm{x})$; 4.-5. aperture deformations (50x, 50x); 6.-7. use-wear at the apex level (100x, 150x); 8. perforated Lithoglyphus apertus shells (Mesolithic) $(\mathrm{scale}=1 \mathrm{~cm}) ; 9$. perforation detail (50x); 10.-11. abrasion marks (100x, 100x). 
The technological observations made on the Lithoglyphus naticoides shells also apply to the eight Theodoxus danubialis shells (Fig. 4.1). The perforations are slightly irregular with small fractures, which suggests the technique of production was indirect percussion (Fig. 4.2). Deformation of the perforation and the aperture were also noted (Fig. 4.3-4). The diameter of the perforations varies between 2 and $4 \mathrm{~mm}$.

In the case of the three Tritia sp. shells the perforation is also located on the last whorl (Fig. 4.5). The perforation diameter is about $4 \mathrm{~mm}$ in all specimens. Accentuated use-wear is visible, strongly deforming the perforation toward the aperture (Fig. 4.7-8). In one case, the presence of red pigment was identified.

The single Zebrina detrita shell (Fig. 4.9) from Cuina Turcului was perforated through the last whorl, starting from the inside. The main characteristics are the sub-circular shape and irregular edges of the perforation, suggesting the use of pressure technique (Fig. 4.10). No use-wear is visible on this specimen.

\section{Scaphopods}

A single example of a tusk shell bead from the Epi I horizon (Fig. 4.11) is preserved among the shell adornments from Cuina Turcului in the "Vasile Pârvan" Institute of Archaeology. This has a slightly tapering form and represents a short segment of the original shell. Two techniques used for segmentation of tusk shells are known, sawing and bending ${ }^{17}$. Unfortunately, the extremities of this shell are exfoliated (Fig. 4.12) hindering identification of the technique used to produce the bead.

\section{Mammalian teeth}

Eleven perforated canines of Cervus elaphus exist in the collection, of which eight come from the Epi I horizon and three from the Epi II horizon (Tab. 4). The anatomical elements of the tooth are preserved in all specimens. No likely pair was identified. Eight of the canines appear to come from male red deer and three from females.

In the case of the red deer canines from Epi I (Fig. 5.1), the perforation was made through the root of the tooth. Both unifacial (one case) and bifacial (six cases) rotation were employed. On four specimens the perforated area was prepared by longitudinal scraping (Fig. 5.2), the traces being visible on the periphery of the perforations. On one item bifacial longitudinal scraping was applied with the purpose of thinning the piece, and that operation was continued until perforation was achieved. The perforation has an elongated form (Fig. 5.3). Two areas with use-wear were observed on the teeth. The first occurs between the side of the tooth and the perforation which tends to be deformed in this area (Fig. 5.4), while the wall of the perforation was affected by friction with a thread becoming flattened or even with a slight depression (suggesting more prolonged use) and exhibiting macroscopic polish (Fig. 5.5-6). The location of this use-wear indicates the canines were suspended in such a way as to produce the most intense wear along the lateral edges, suggesting they were sewn onto clothing. A second area of use-wear occurs on the lobe of the tooth and consists of flattening of the surface and the development of a macroscopic polish (Fig. 5.7) associated with irregular scratches that are visible under magnification - again, likely the result of friction with clothing.

On the three specimens from the Epi II horizon (Fig. 5.8) perforation was also through the root and bifacial rotation was applied. The surface was prepared by scraping in the case of two teeth (Fig. 5.9). The use-wear pattern is identical to that of the Epi I perforated teeth (Fig. 5.10-11) suggesting the same manner of attachment.

The wild boar lower incisor (Fig. 6.1) was perforated by bifacial rotation. The rotation marks have disappeared suggesting that the piece had been worn for a long time (Fig. 6.2) while on the periphery of the perforation the surface has become flattened, with fine scratches (Fig. 6.3).

On the wolf incisor (Fig. 6.4) a more complex procedure was applied: first, thinning of the surface by slightly oblique scraping, creating a depression with a small oval perforation (Fig. 6.5), then finishing of the perforation by bifacial rotation. No use-wear was noted.

The herbivore incisor (Fig. 6.6) was modified in a unique manner; the root was removed by sawing (Fig. 6.9) followed by bending, and the perforation was made by bifacial rotation (Fig. 6.10).

On the beaver incisor (Fig. 6.7) preparation of the perforation was initiated through longitudinal scraping, followed by perforation by rotation. A transverse break across the perforation (Fig. 6.11) indicates the latter operation was not finished.

The last (indeterminate) tooth (Fig. 6.8) is fractured and preserves only a part of a perforation, which most likely was accomplished through rotation (Fig. 6.12).

17 Vanhaeren, d'Errico 2001. 

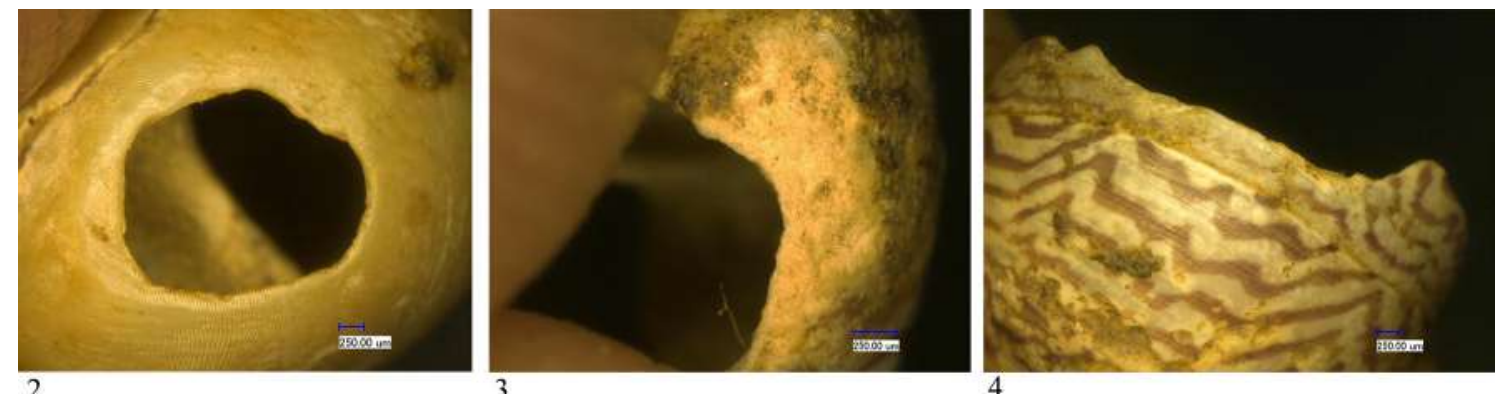

2

3

4
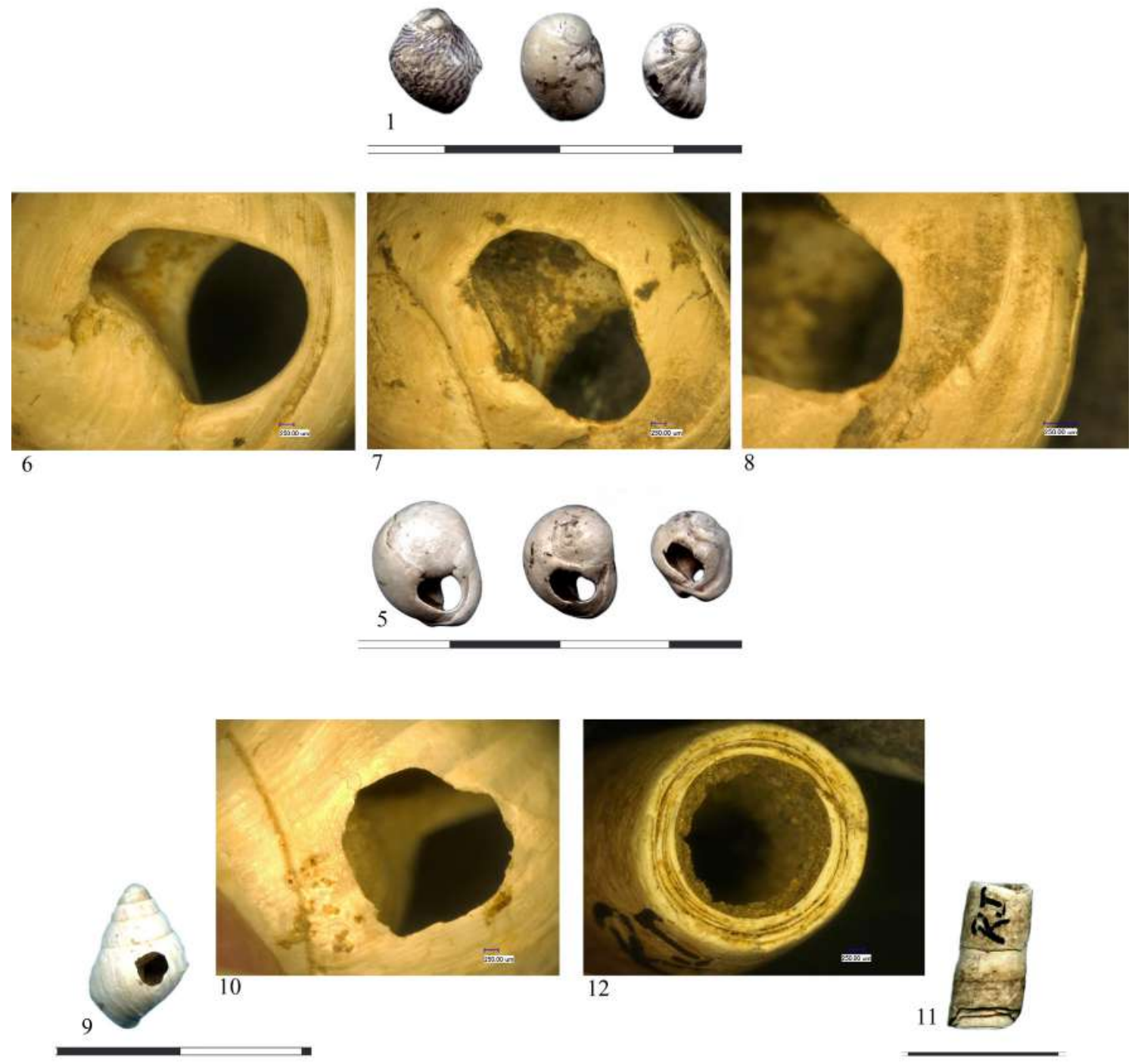

12

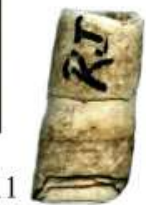

Figure 4. 1. Perforated Thedoxus danubialis shells (Mesolithic) $(\mathrm{scale}=1 \mathrm{~cm}) ; 2$. perforation detail $(50 \mathrm{x}) ; 3$. perforation deformation $(100 \mathrm{x})$; 4. aperture deformation (50x); 5. perforated Tritia neritea shells (Mesolithic) $($ scale $=1 \mathrm{~cm}) ; 6 .-7$. perforation details $(50 \mathrm{x}, 50 \mathrm{x})$; 8. perforation deformation $(100 \mathrm{x})$; 9 . perforated Zebrina detrita shell (Mesolithic) $(\mathrm{scale}=1 \mathrm{~cm}) ; 10$. perforation detail $(50 \mathrm{x})$; 11. Antalis $\mathrm{sp}$. shell (Mesolithic) $($ scale $=1 \mathrm{~cm}) ; 12$. detail of edge $(50 \mathrm{x})$. 

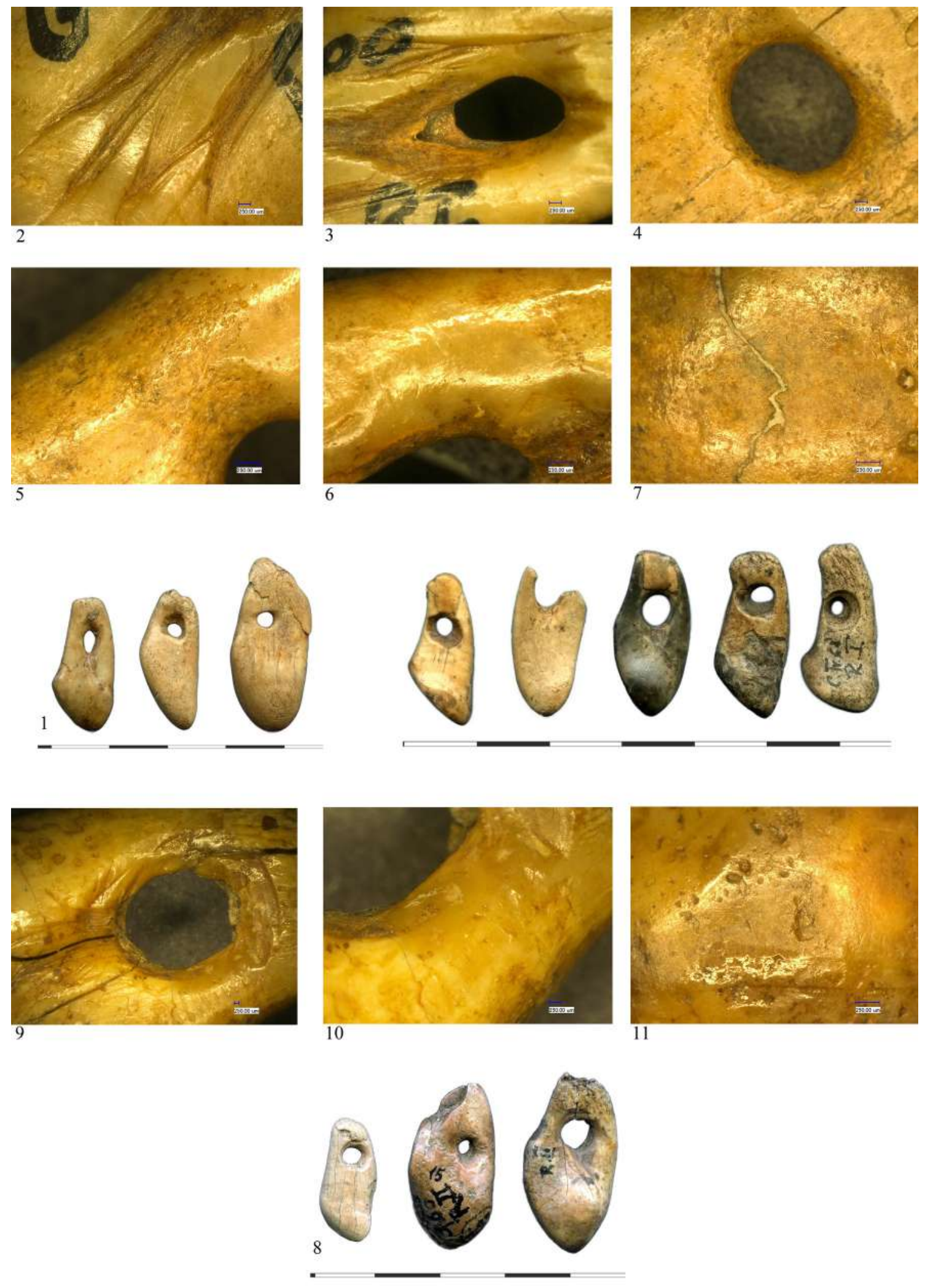

Figure 5. 1. 8 Perforated Cervus elaphus teeth (Mesolithic) $($ scale $=1 \mathrm{~cm})$; 2. scraping marks (50x); 3.-4., 9. perforation details $(30 \mathrm{x}, 50 \mathrm{x}, 20 \mathrm{x})$; 5.-6., 10. use-wear marks at the perforation level (100x, 100x, 50x); 7., 11. use-wear marks at the crown level (100x, 100x). 


\section{Bone and antler}

The only bone pendant (length $-2.5 \mathrm{~cm}$, width $-2.1 \mathrm{~cm}$, thickness $-0.4 \mathrm{~cm}$, perforation diameter $-0.5 \mathrm{~cm}$, (Fig. 7.1) from Cuina Turcului (Epi II horizon, Tab. 4) was made on a flat blank from a long bone shaft, seemingly obtained by sawing (Fig. 7.2) followed by bending, with the segmentation marks still visible at the proximal and distal extremities. The superior surface preserves the original bone morphology. The inferior surface was regularized by longitudinal scraping (Fig. 7.3). The perforation was obtained by rotation (Fig. 7.4) starting on the inferior surface, resulting in a hole with a conical profile. Specks of a red substance (Fig. 7.5) are visible on the edges of the perforation and toward the distal extremity.

The antler (Cervus elaphus species) object (Fig. 7.6) from the Epi II horizon is fractured, but the presence of a perforation suggests its use as a pendant (Tab. 4). The debitage procedure used to produce the flat blank could not be determined as all manufacturing traces were erased when the inferior surface was regularised by scraping (Fig. 7.7). At the distal end, the piece has a perforation made by unifacial rotation starting from the superior surface (Fig. 7.8). On this surface are a series of nine parallel oblique lines (Fig. 7.9) produced by sawing - they are deep with an asymmetric V-shaped profile. The piece is broken at the proximal end, but four transverse incisions (Fig. 7.10) are still visible.

In the case of the surviving Siluris glanis vertebra (Fig. 7.11, right) recovered from the Epi II horizon (Tab. 4), the vertebral spines were detached by bending. The central perforation was produced by bifacial rotation.

\section{Adornments from the Early Neolithic horizons}

The perforated gastropod shells from Early Neolithic contexts at Cuina Turcului curated at the "Vasile Pârvan" Institute of Archaeology comprise those of marine (Columbella sp.) and freshwater (Lithoglyphus naticoides and Theodoxus danubialis) species.

\section{Gastropods}

The shell of Lithoglyphus naticoides (Fig. 8.1) has a perforation with a more-or-less rectangular outline (Fig. 8.2), suggesting the use of indirect percussion. Use-wear occurs in the area between the perforation and the aperture; the perforation has acquired a concave morphology with a corresponding deformation of the aperture (Fig. 8.3), resulting from thread pressure.

The same perforation technique was applied to the shell of Theodoxus danubialis (Fig. 8.4), though the aperture and the perforation (Fig. 8.5-6) do not show such advanced use-wear.

The assemblage is completed by a perforated shell of Columbella sp. (Fig. 8.7). The shell is heavily worn with a subcircular perforation (Fig. 8.8) that shows no manufacturing marks although the "flanged" walls suggest the perforation was achieved by grinding. There is also a deformation of the perforation wall in the form of a small concavity, resulting from thread pressure (Fig. 8.9, 11). The shell apex is fractured and shows intense use-wear polish (Fig. 8.10) ${ }^{18}$.

Scaphopods

One tubular bead made from a tusk shell (Antalis sp.) (Fig. 8.12) has extremely advanced use-wear on the dorsal (tip) end. This end was shaped by abrasion but also shows a marked concavity (Fig. 8.13-14) that corresponds with a flattened area on the shell exhibiting macroscopic polish (Fig.. 8.15), which clearly results from use as an adornment and suggests the piece was worn for a long period. The ventral end of the shell appears to have been fractured post-depositionally.

\section{Bivalves}

Two valves of Unio sp. (Fig. 9.1) have a perforation located approximately in the same place, below the umbo. The perforation is sub-circular with an irregular outline (Fig. 9.2). In places the perforation edge has a faceted aspect indicating impact points; there are also cracks starting from some of the impact points, suggesting the application of indirect percussion (Fig. 9.3-4). On one of the valves a second perforation appears to have been initiated but not finished, which seems to confirm the use of this technique (Fig. 9.5). Experiments on modern specimens ${ }^{19}$ suggest indirect percussion was applied bilaterally and repeatedly in order to create a perforation with the required diameter. We could not identify use-wear on the perforation walls of the specimens from Cuina Turcului; hence, their use as pendants is hypothetical.

\footnotetext{
${ }_{18}$ The piece continued to be used even after the apex was fractured.

${ }^{19}$ Sztancs et al. 2016.
} 


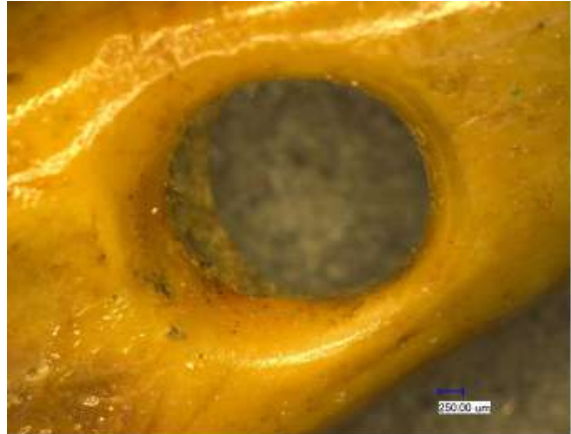

2

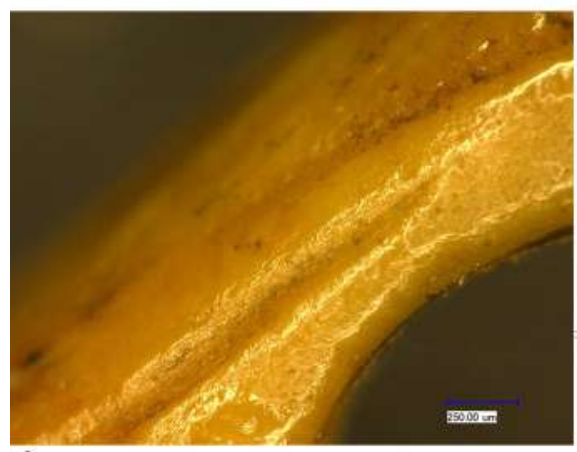

3

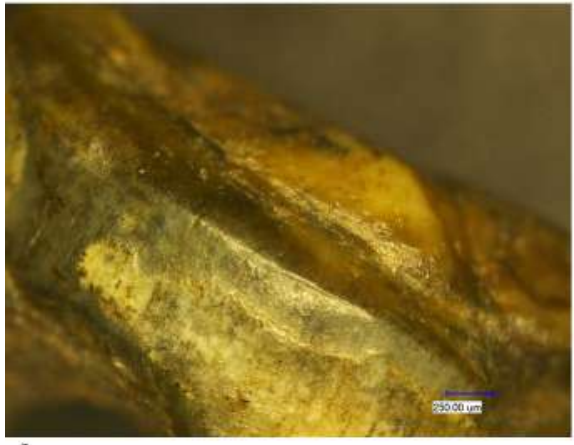

9

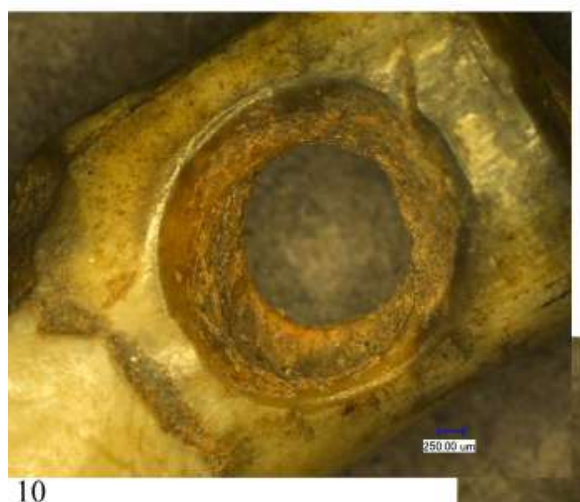

10
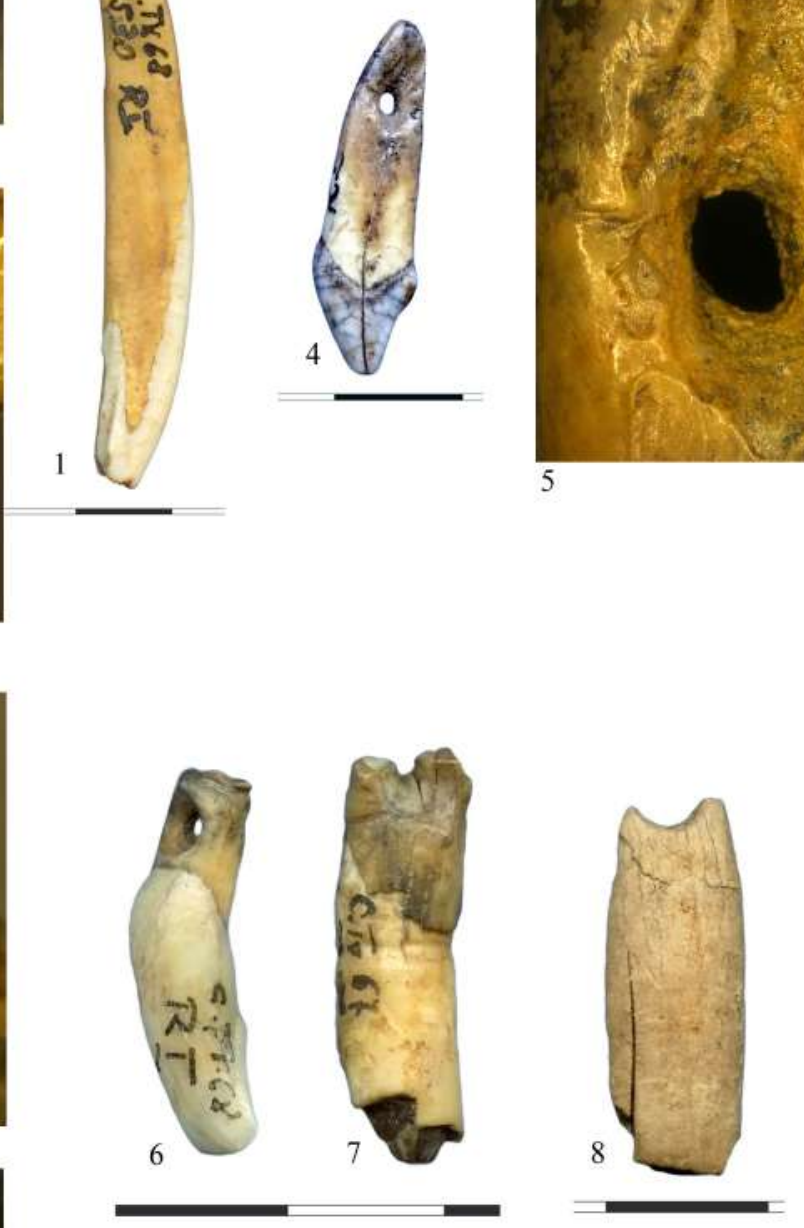
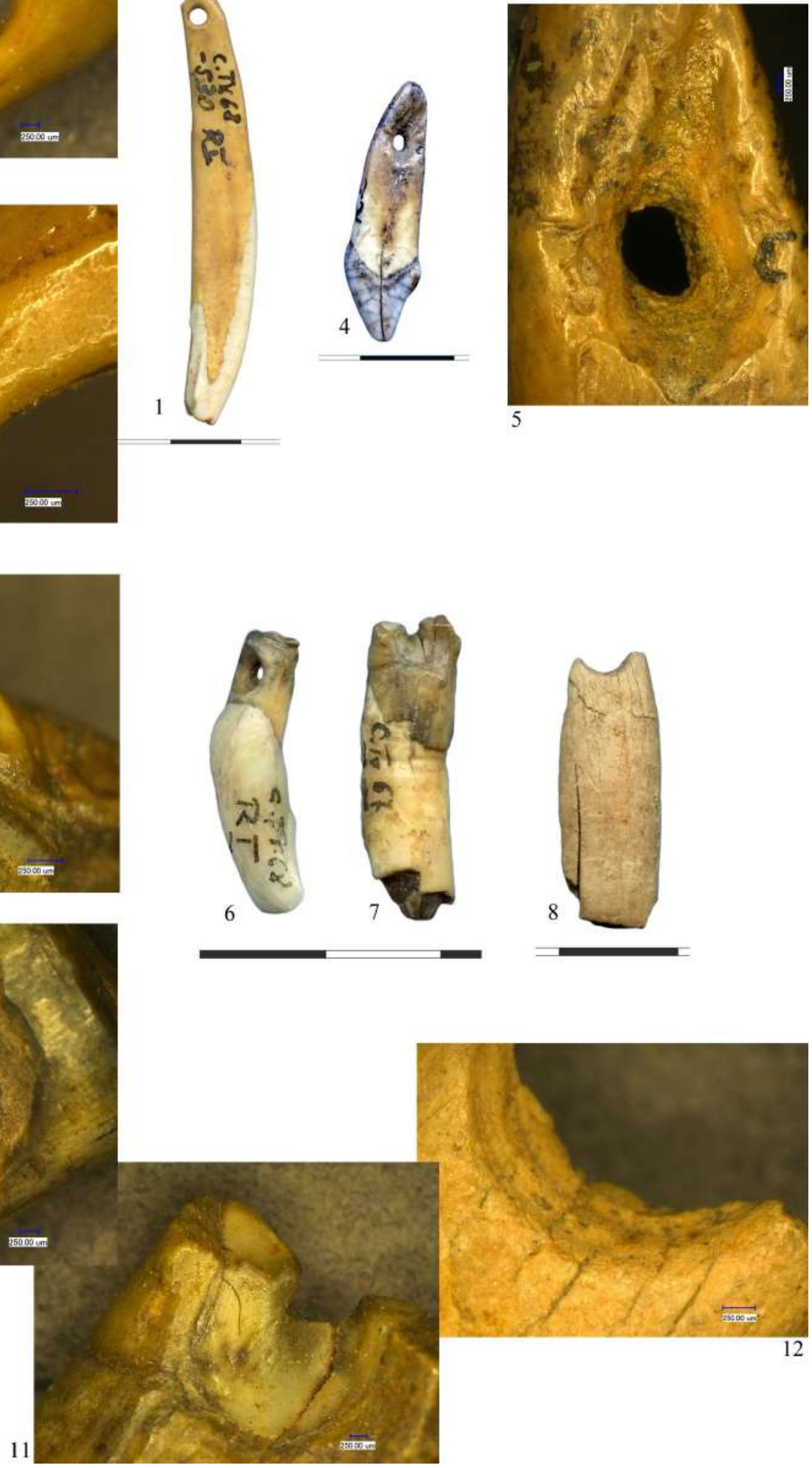

Figure 6. 1. Perforated wild boar lower incisor (Mesolithic) $(\mathrm{scale}=1 \mathrm{~cm}) ; 2 ., 5$. perforation detail $(50 \mathrm{x}, 50 \mathrm{x})$; 3. use-wear marks at the perforation level (150x); 4. perforated wolf incisor (Mesolithic) $(\mathrm{scale}=1 \mathrm{~cm}) ; 6$. perforated herbivore incisor (Mesolithic) $(\mathrm{scale}=1 \mathrm{~cm})$;

7. perforated beaver incisor (Mesolithic); 8. perforated indeterminate tooth (Mesolithic) (scale =1 cm); 9. sawing marks $(100 x)$; 10.-12. perforation details $(50 \mathrm{x}, 50 \mathrm{x}, 75 \mathrm{x})$. 

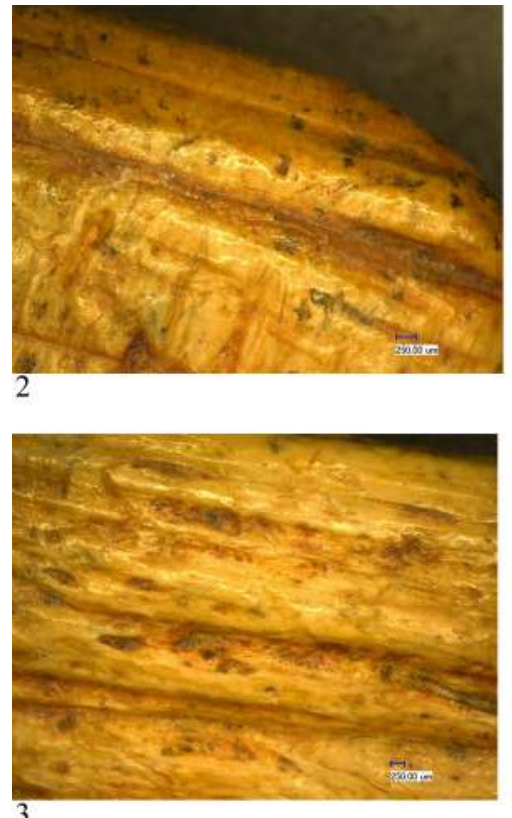

3
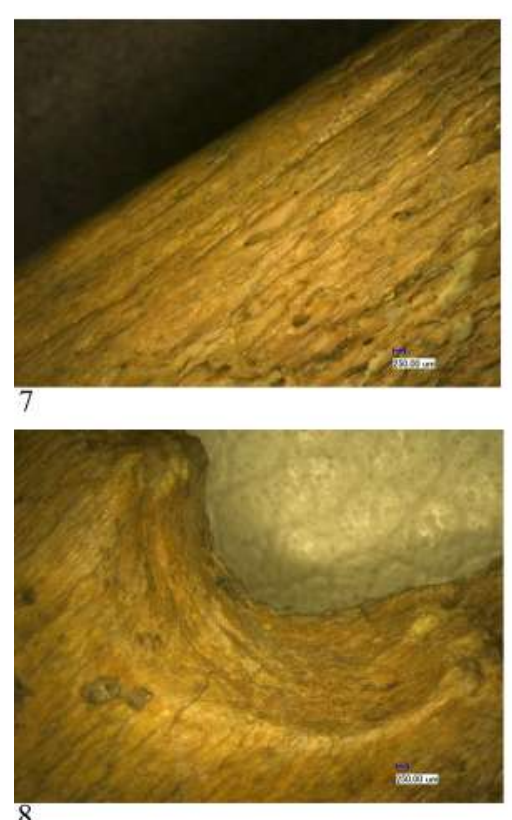

8
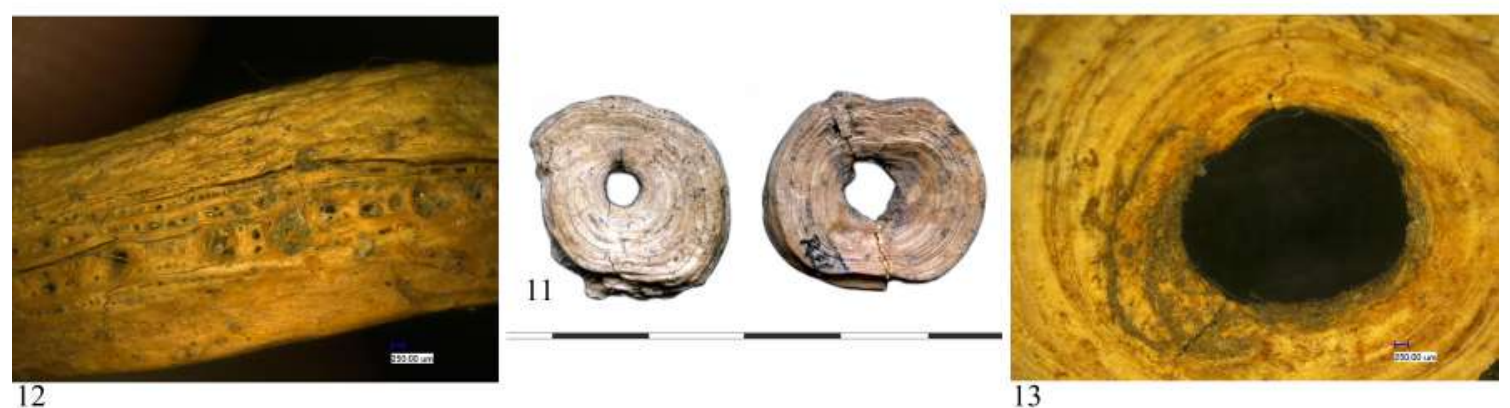

Figura 7. 1. Bone pendant (Mesolithic) (scale $=1 \mathrm{~cm})$; 2. sawing marks (50x); 3., 7. scraping marks (35x, 30x); 4., 8., 13. perforation details $(35 \mathrm{x}, 30 \mathrm{x}, 30 \mathrm{x}) ; 5$. red ochre spots $(150 \mathrm{x}) ; 6$. antler pendant (Mesolithic) $(\mathrm{scale}=1 \mathrm{~cm}) ; 9 .-10$. decoration details $(20 \mathrm{x}, 150 \mathrm{x})$;

11. perforated fish vertebrae (Mesolithic and Early Neolithic) $($ scale $=1 \mathrm{~cm}) ; 12$. detail of edge (30x). 


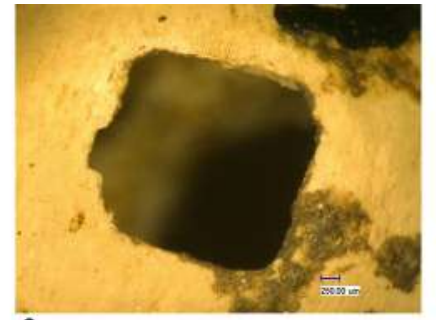

2

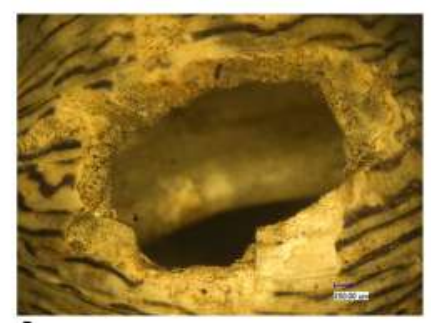

5
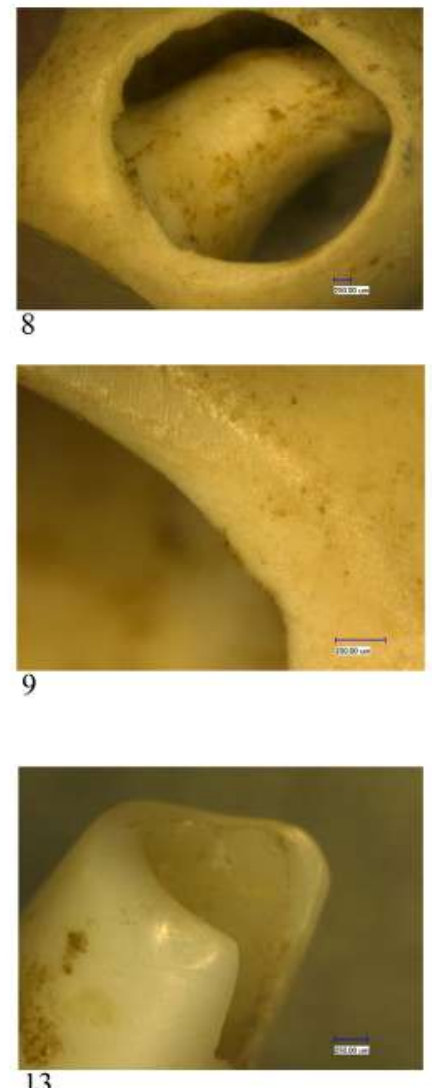

13

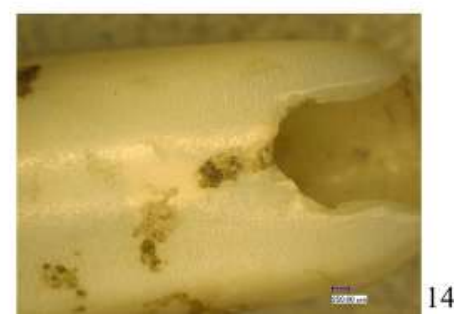

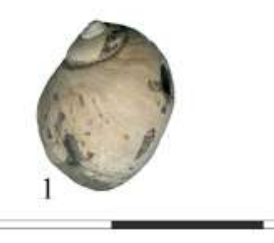
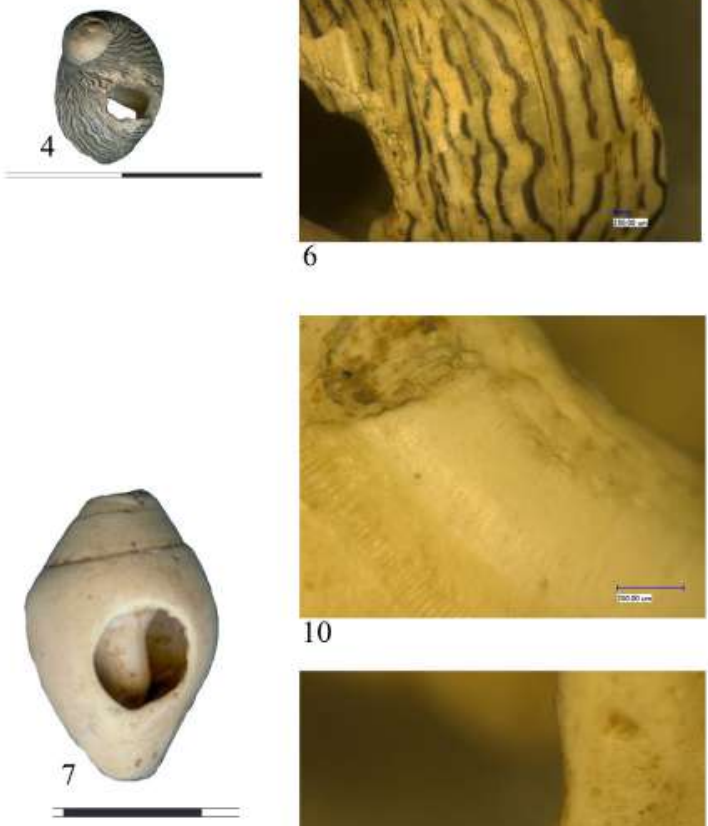

10

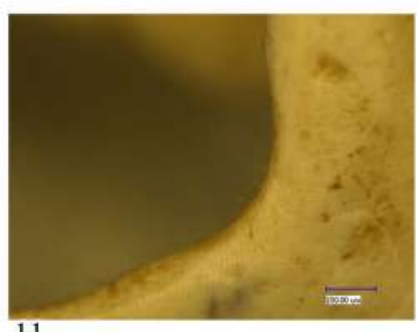

11

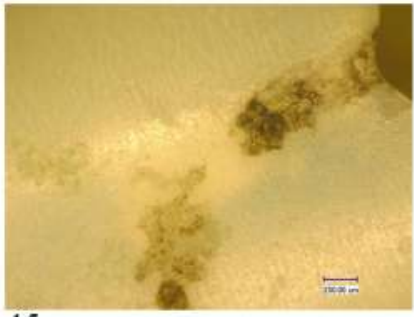

15

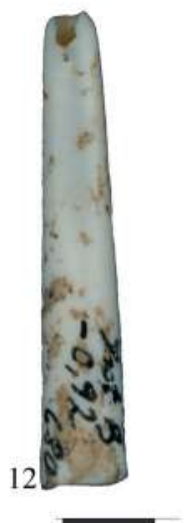

Figure 8. 1. Perforated Lithoglyphus naticoides shell (Early Neolithic) (scale $=1 \mathrm{~cm}) ; 2 ., 5 ., 8$. perforation details $(50 \mathrm{x}, 50 \mathrm{x}, 50 \mathrm{x})$; 3., 6. aperture deformation (50x, 50x); 4. Thedoxus danubialis shell (Early Neolithic) $(\mathrm{scale}=1 \mathrm{~cm}) ; 7$. perforated Columbella sp. shell (Early Neolithic) $($ scale = $1 \mathrm{~cm}) ; 9$. ., 11. use-wear at the perforation level $(150 \mathrm{x}, 200 \mathrm{x}, 150 \mathrm{x}) ; 10$. use-wear at the apex level (200x); 12. Antalis sp. shell $($ Early Neolithic) $($ scale $=1 \mathrm{~cm}) ; 13 .-14$. deformation of the edge $(100 \mathrm{x}, 50 \mathrm{x}) ; 15$. flattened facet $(100 \mathrm{x})$. 


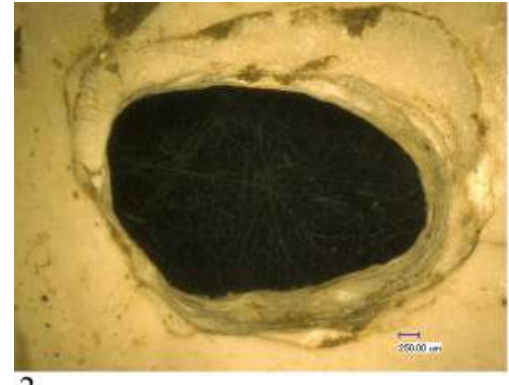

2

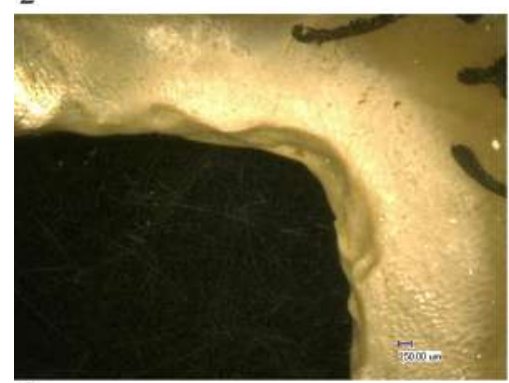

3

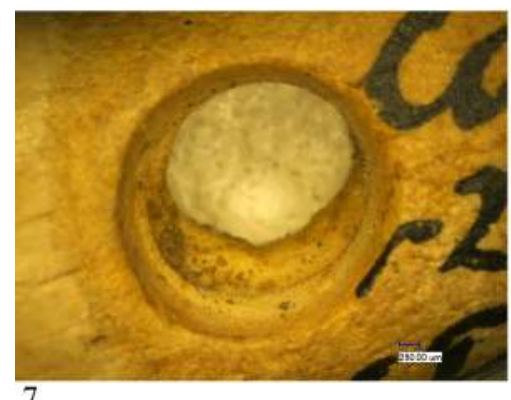

7

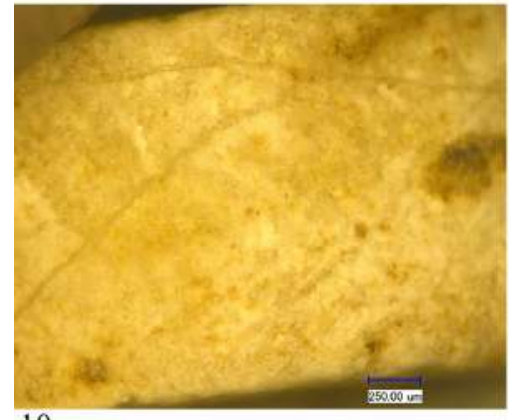

10

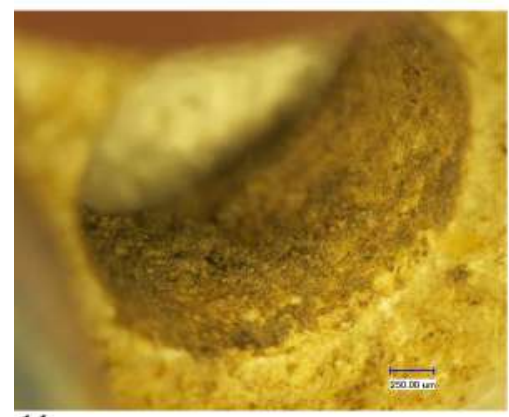

11

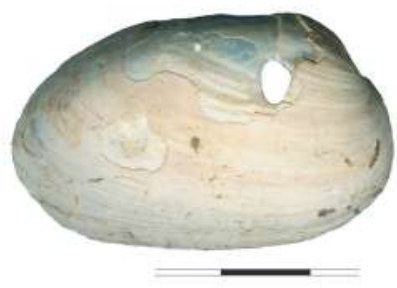

1
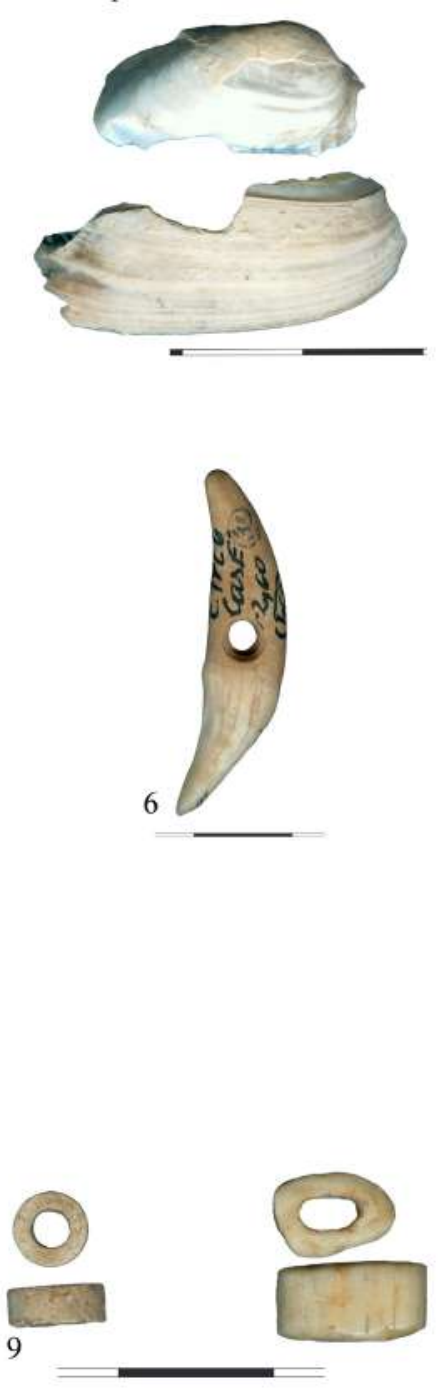

9

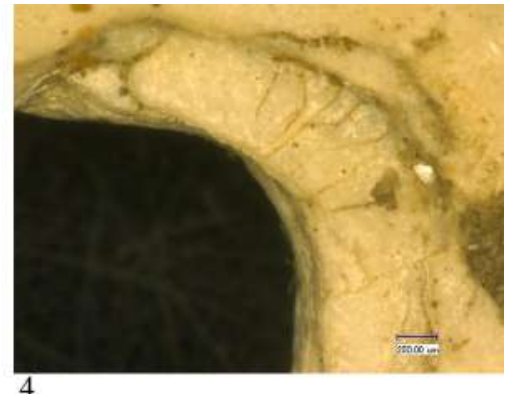

4
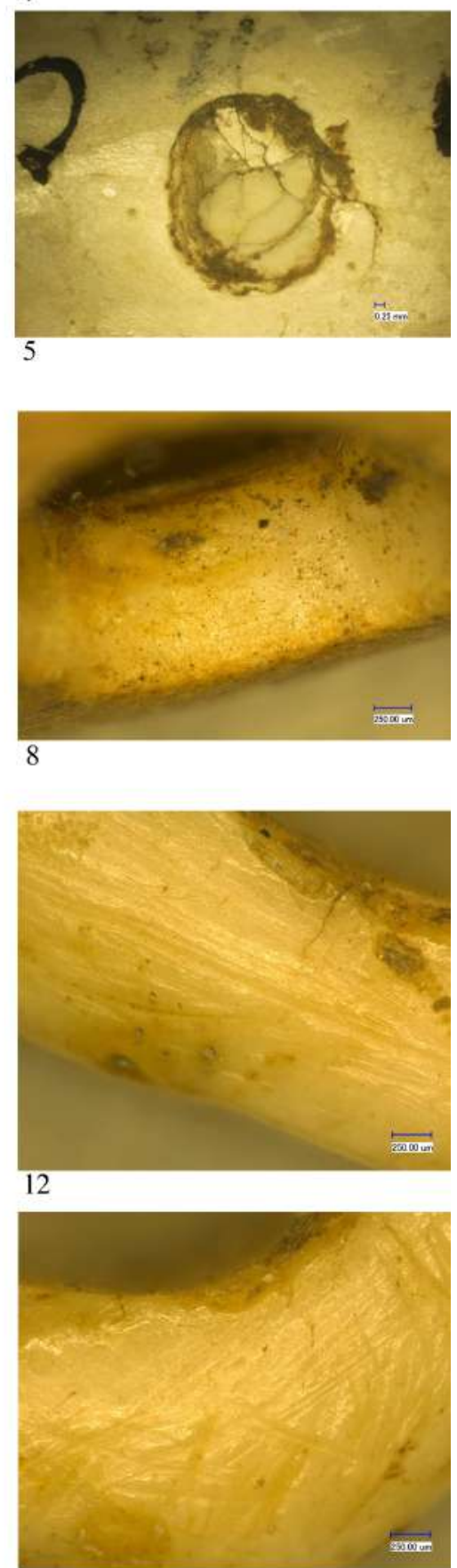

13

Figure 9. 1. Perforated Unio sp. valves (Early Neolithic) $(\mathrm{scale}=1 \mathrm{~cm}) ; 2 .-4$. perforation details $(50 \mathrm{x}, 30 \mathrm{x}, 100 \mathrm{x}) ;$ 5. unfinished perforation $(25 \mathrm{x}) ; 6$. perforated Vulpes vulpes canine (Early Neolithic) $(\mathrm{scale}=1 \mathrm{~cm}) ; 7 ., 11$. perforation detail $(50 \mathrm{x}, 100 \mathrm{x}) ; 8$. use-wear at the perforation level $(100 \mathrm{x}) ; 9$. bone beads (Early Neolithic) $($ scale $=1 \mathrm{~cm}) ; 10$. edge detail $(100 \mathrm{x}) ; 12$. sawing mars $(100 \mathrm{x})$;

13. sawing and abrasion marks (100x). 

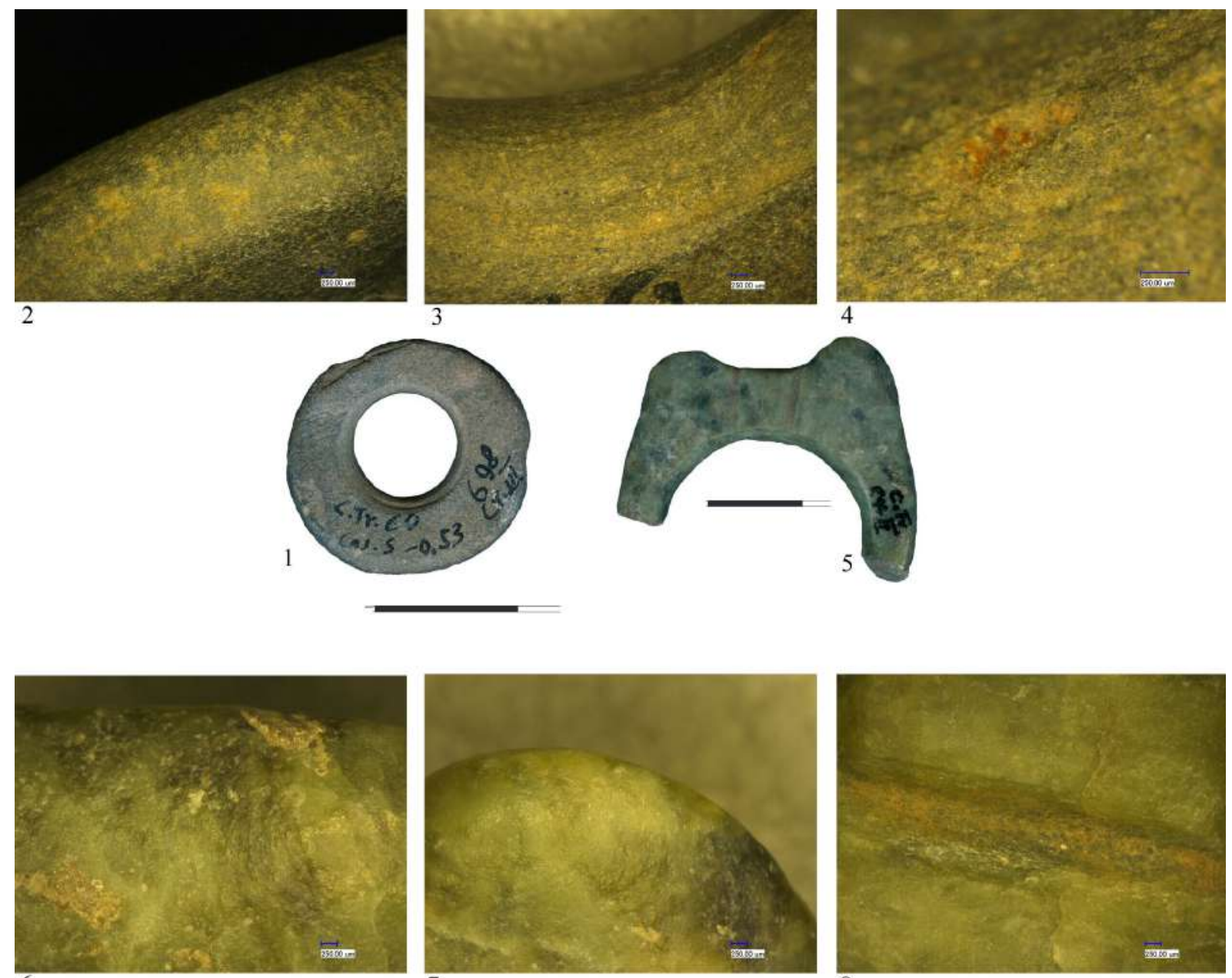

6
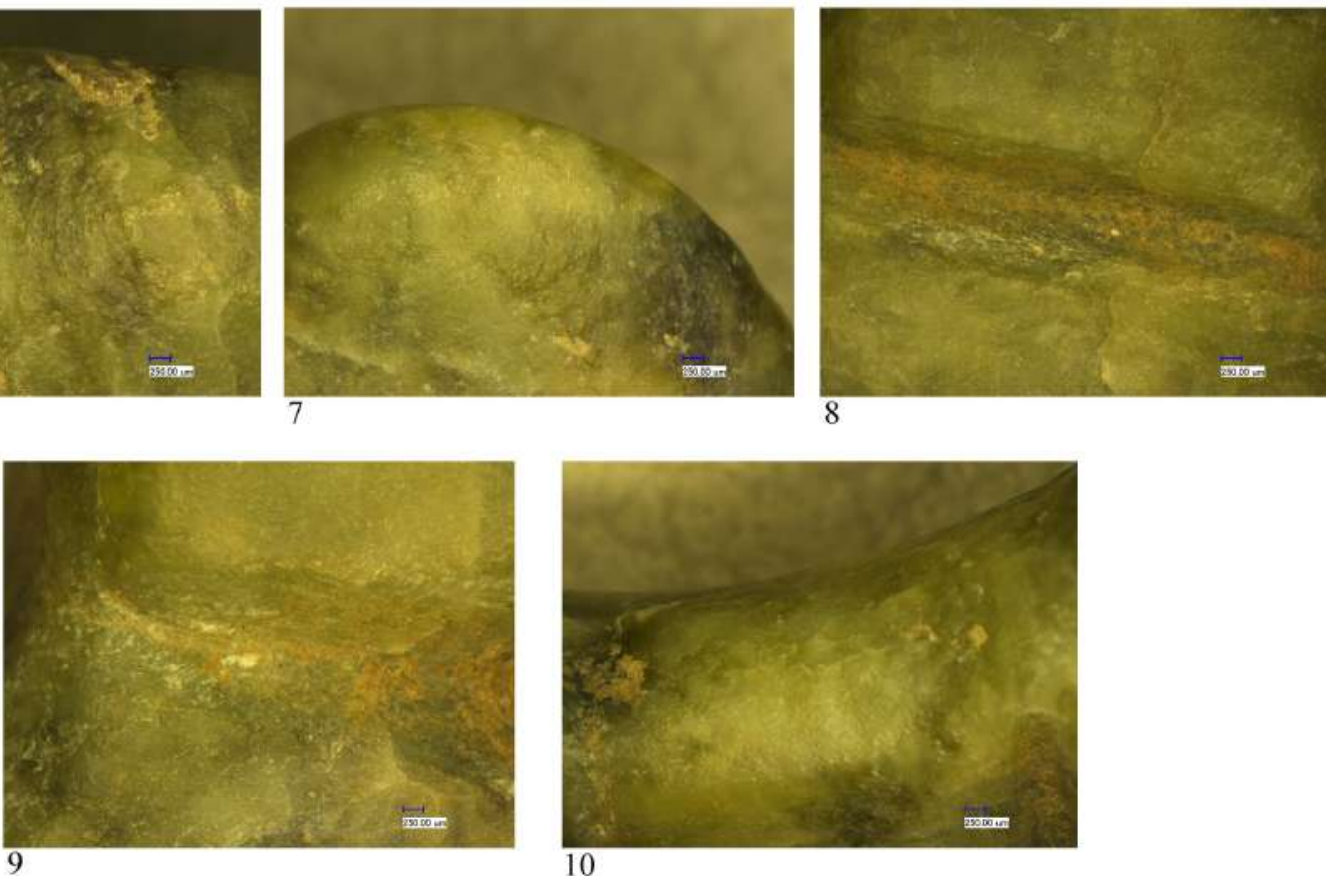

10

Figure 10. 1. Stone disc (Early Neolithic) (scale $=1 \mathrm{~cm}) ; 2$. edge detail $(35 \mathrm{x}) ; 3 ., 10$. perforation details $(50 \mathrm{x} ; 50 \mathrm{x})$; 4. red ochre spots (150x); 5. belt element (Early Neolithic) (scale $=1 \mathrm{~cm}) ;$ 6.-7. abrasion marks $(50 \mathrm{x}, 50 \mathrm{x}) ; 8 .-9$. grooving details $(50 \mathrm{x}, 50 \mathrm{x})$. 


\section{Mammalian teeth}

Only a canine of Vulpes vulpes (Fig. 9.6) is present in the surviving collection. It was perforated in the middle by bifacial rotation (Fig. 9.7). The manufacturing marks are still visible, suggesting the piece received little use (Fig. 9.8).

Two other pieces were made from Sus sp. canines through longitudinal bipartition of the tooth. These are fragments that preserve parts of one or two perforations, and may come from utilitarian tools rather than adornments.

\section{Bone}

Two bone beads are present in the collection (Fig. 9.9). One is a disc bead made on a flat blank but we were unable to determine the debitage procedures, the rim having been heavily abraded to obtain the circular morphology (Fig. 9.10). Perforation was achieved by bifacial rotation performed centrally (Fig. 9.11). The second piece was made on a volume blank and has a sub-oval outline reflecting the bone morphology. Segmentation was performed at both ends by sawing (Fig. 9.12) followed by abrasion of the segmentation surfaces (Fig. 9.13). The medullary channel was used as the perforation.

The surviving belt elements ("buckles") mentioned in previous publications are re-interpreted by us as fragments of fishing hooks, and as such do not fall within the scope of the present paper.

In the case of the catfish (Silurus glanis) vertebra (Fig. 7.11, left) from the "Cris II" horizon (Tab. 4), like that from the Epi II horizon the vertebral spines were detached by bending (Fig. 7.12) and the central perforation achieved by bifacial rotation (Fig. 7.13). The beginning of use-wear development, in the form of macroscopic polish and fine scratches, is visible on the periphery of the perforation.

\section{Stone}

Two stone objects were available for analysis. One qualifies as a disc bead or ring (Fig. 10.1). Both faces of the piece were intensely abraded (Fig. 10.2), and the central perforation was made by bifacial rotation (Fig. 10.3). Red spots, possibly ochre, were also observed on both faces of the piece (Fig. 10.4)

The second item was possibly a belt element ${ }^{20}$ made of greenish stone (Fig. 10.5). The distinctive shape was created by cutting and abrasion (Fig. 10.6-7). At one end, two grooves were incised on both faces (Fig. 10.8-9). The perforation has a biconvex profile and was created by bifacial rotation (Fig. 10.10) then enlarged by scraping.

\section{Discussion and conclusions}

The original collection

A comparison of the adornments listed in the field notes (Tab. 2) and in subsequent publications (Tab. 3) reveals discrepancies and inconsistencies, which calls for comment:

1. It is likely that some artefacts were recognized only after washing and sorting of the archaeological finds, which would explain some of the differences between the field notes and the published accounts.

2. Păunescu's descriptions of the adornments included some finds from 1964, but not all of them. A fragment of a bone ring was recorded in 1964 field notes and in V. Boroneanț's publication21 but was not mentioned by Păunescu. Also, the number of small "circular" beads in the field notes (11 beads - Tab. 2) does not accord with either the number illustrated by Boroneanț $t^{22}(4)$ or reported by Păunescu ${ }^{23}(4+3)$, suggesting that some items had been misplaced before any published account was produced.

3. Unfortunately, there is no way of matching many of the items in the existing collection or publications to those described in the field notes. It is thus impossible to determine which species formed the small 'hoard' of 11 perforated snail shells in S.V (Tab. 2).

4. Păunescu's published account of the adornments from Cuina Turcului mentions 17 "tubular" beads found in the "Cris III" horizon ${ }^{24}$, which we presume correspond to the group of 16 such beads plus one isolated find described in his field notes. He compared these to the hoard of cylindrical and barrel-shaped beads

\footnotetext{
${ }^{20}$ Bonnardin 2009.

${ }^{21}$ Boroneant 1970, 409; a number was never reported.

${ }^{22}$ Boroneanț 1970, 410, Fig. 3.6-9. The number was never reported.

${ }^{23}$ Păunescu 1978, 33, "four small beads made of bone and teeth" and "three circular beads of whitish limestone"; Five were illustrated - Păunescu 1978, Fig. 12.7, Fig. 14.17, 18, 20, 22.

${ }^{24}$ Păunescu 1978, 33.
} 
that were found in a pot at Lepenski Vir and assigned to occupation phase IIIb (Starčevo-Criș culture) $)^{25}$. The Lepenski Vir beads were made mainly from Spondylus shell and nephrite ${ }^{26}$. It is not clear from the poor quality photograph published by Păunescu ${ }^{27}$ or his written descriptions whether any of the examples from Cuina Turcului were made from Spondylus shell, although the isolated bead was described in the field notes as made from "stone".

5. All earlier publications make a distinction (based on shape) between bone buckles and bone hooks. Since our study of the existing items indicates that the two categories cannot be separated morphologically, they have all been classified as "hooks" and are not discussed further in this paper.

\section{The existing collection}

For some of the artefacts - mainly the perforated mollusc shells and mammal teeth - no information was marked (or survived) on the object, making identification of context difficult. Nevertheless, for certain pieces we were able to recover some contextual information by combining the marked information with that in the field notes and publications (Tab. 4).

It has not been possible to establish whether there was any spatial association between the perforated tooth pendants or between the tooth pendants and other types of adornment. Several tooth pendants were found in 1967 and 1968 , possibly in the same area, but there is no record of them in the field notes. Nevertheless, Tab. 4 indicates that in at least 10 cases (six "Epipalaeolithic" and four Early Neolithic), adornments were associated with occupation or activity areas, as indicated by the presence of hearths and agglomerations of other finds (pottery, stone tools and faunal remains). Although human remains were found in the Early Neolithic horizons - possibly from disturbed burials - there is no indication in the field notes that adornments were found in close proximity to them.

\section{Cuina Turcului and the Iron Gates}

The personal adornments found at Cuina Turcului were assigned by the excavators to two broad chronological phases, "Epipalaeolithic" and Early Neolithic. We have previously expressed reservations about the use of the term "Epipalaeolithic" in the context of the Iron Gates and prefer to include it in our definition of "Mesolithic". In our view, the Mesolithic begins with the expansion of human populations out of southern refugia following the Last Glacial Maximum (LGM) and ends with the transition to farming. Thus, we recognize three broad chronological divisions within the Iron Gates Mesolithic based on climatostratigraphy: Early (corresponding to the Lateglacial period, ca 12,700-9650 cal BC), Middle (Early Holocene I, ca 9650-7200 cal BC), and Late (Early Holocene II, ca 7200$6000 \mathrm{cal} \mathrm{BC})^{28}$. Based on the available ${ }^{14} \mathrm{C}$ dates for the "Epipalaeolithic" horizons at Cuina Turcului, as a working hypothesis we suggest that Păunescu's "Epi I" horizon corresponds primarily to the Bølling-Allerød interstadial (ca 12,700-11,000 cal BC) falling within our Early Mesolithic phase and that his "Epi II" horizon dates to Early Holocene I and the transition from the Younger Dryas corresponding to the first part of our Middle Mesolithic phase.

The personal adornments from the "Epipalaeolithic" horizons at Cuina Turcului are typical of those used by postglacial foragers in the Iron Gates, on both sides of the Danube ${ }^{29}$. Their distribution among the various types is summarized in Tab. 5.

Although the surviving ornaments from Cuina Turcului (Tab. 4) are only a subset of those recovered in the 1964-9 excavations, it is nevertheless interesting that all the perforated gastropod shells that can be assigned to a specific "Epipalaeolithic" horizon appear to have come from Epi II, and so may belong to the Middle Mesolithic.

Among the shell adornments in the Epi II ("Middle Mesolithic") series from Cuina Turcului, the most numerous are the perforated shells of freshwater gastropods (mainly Lithoglyphus spp.). Such adornments were also found in Late Mesolithic funerary contexts at Schela Cladovei ${ }^{30}$ and Vlasac ${ }^{31}$, as well as in the form of a small "hoard" at Ostrovul Banului $^{32}$. They continue to be found during the Early Neolithic, with a few examples at Cuina Turcului.

Exotic shells were represented at Cuina Turcului by Antalis sp., Columbella sp., Tritia sp. and, possibly, Spondylus sp.

Other than at Cuina Turcului, the presence of beads made from segmented tusk shell was noted in "Epipalaeolithic" deposits at Climente II Cave and at the open-air site of Icoana in what is thought to be a Middle Mesolithic

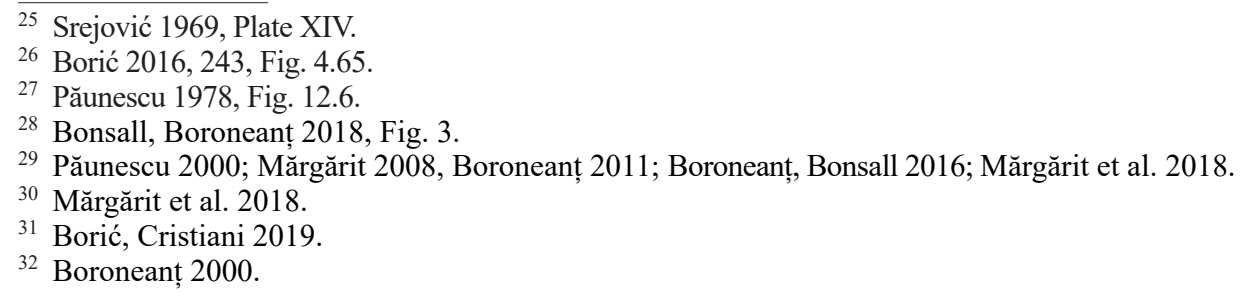


Table 3. Published artefacts versus artefacts recorded in field notes $(*$ indicates the presence of artefacts when the number of examples was not specified). Categories of artefact follow the descriptions in publications/field notes.

\begin{tabular}{|c|c|c|c|}
\hline & & Publications & Fieldnotes \\
\hline \multirow{6}{*}{ Epi } & Perforated snail shells & $*$ & 24 \\
\hline & Perforated teeth & 15 & 1 \\
\hline & Perforated fish vertebrae & 2 & 1 \\
\hline & Small circular bone beads & & 1 \\
\hline & Rectangular bone pendant & 1 & \\
\hline & Tusk shell ("Dentalium") "fragments" & * & \\
\hline \multirow{13}{*}{$\mathbf{E N}$} & Bone pendants & 4 & \\
\hline & Perforated snail shells & 73 & 34 \\
\hline & Perforated teeth & 5 & 1 \\
\hline & Perforated fish vertebrae & 1 & \\
\hline & Small circular bone beads & 4 & 9 \\
\hline & "Tubular" beads & 17 & 17 \\
\hline & Bone buckles & 8 & 4 \\
\hline & Bone hooks & 7 & 3 \\
\hline & Bone ring & 1 & 1 \\
\hline & Perforated stone artefacts (pendants) & 4 & 2 \\
\hline & Stone pendant with groove/ Polished small stone object & 1 & 1 \\
\hline & Bone "buttons" & 3 & 3 \\
\hline & Perforated Unio shells & $>2$ & 2 \\
\hline
\end{tabular}

horizon $^{33}$, all apparently in non-funerary contexts. The origin of the tusk shells found in Mesolithic and Early Neolithic contexts in these sites is a source of debate. While the shells can be collected today on beaches around the Mediterranean, they also occur as fossils in Neogene calcareous deposits in the Iron Gates and could have been picked up along the banks, beaches and beds of rivers dissecting these deposits ${ }^{34}$. Arguably, the same applies to the perforated gastropod shell from the Early Neolithic site at Knjepište in the downstream area of the Iron Gates. From the published illustration ${ }^{35}$ this resembles the extinct marine gastropod, Terebralia bidentata. Fossils of this species certainly occur in the Iron Gates region. For example, they have been found (along with tusk shells and other marine molluscs) eroding from Miocene marls along the course of the River Curchia near Orşova ${ }^{36}, \mathrm{ca}_{27} \mathrm{~km}$ straight-line distance from Cuina Turcului and ca $45 \mathrm{~km}$ from Knjepište.

A perforated shell of Columbella sp. was found in the Early Neolithic deposits at Cuina Turcului. Shells of this species also occurred in an Early Neolithic context at Lepenski Vir (see below), while at Vlasac they occurred in contexts dated to the Late Mesolithic, including a burial where they were associated with modified Rutilus sp. pharyngeal teeth ${ }^{37}$.

The occurrence of Spondylus shell at Cuina Turcului is less well documented. At Lepenski Vir on the Serbian bank of the Danube, a hoard ("Hoard I") deposited in an Early Neolithic ceramic vessel, "...consisted of 62 cylindrical Spondylus beads, three disc-shaped stone beads, four marine gastropod shells of Columbella rustica used as beads, five green cylindrical beads of nephrite and jade (...), one perforated bone button and one (possibly phallic) bone pendant ..." ${ }^{38}$. Păunescu ${ }^{39}$ illustrated a string of 16 beads from Cuina Turcului from the "Cris III" horizon that he

\footnotetext{
33 Mărgărit et al. 2018, Tab. 1.

34 Grossu 1970, 45.

35 Stanković 1986, Fig. 5.8.

36 Tiță 2007.

37 Borić, Cristiani 2019.

38 Borić 2016, 242.

39 Păunescu 1978, Fig. 12.6.
} 
Table 4. Archaeological contexts of adornments in the existing collection from Cuina Turcului (based on information written on the artefact correlated with information in the field notes).

\begin{tabular}{|c|c|c|c|c|}
\hline Id. & Category & Age & Archaeological context & Comments \\
\hline 1 & Perforated incisor (Sus scrofa) & \multirow[t]{15}{*}{ Epi I } & 1969, Cas.Ș, $5.30 \mathrm{~m}$ & hearth nearby \\
\hline 4 & Antler pendant & & 1969, Cas.Ș, 5.50 m, 712 & hearth nearby \\
\hline 10 & Antalis bead & & & \\
\hline 11 & Perforated incisor (Canis sp.) & & & \\
\hline 12 & Perforated incisor (Castor fiber) & & 1967 & \\
\hline 13 & Perforated tooth (indet.) & & 1968 & \\
\hline 14 & Perforated incisor (Cervus elaphus) & & & \\
\hline 15 & Perforated incisor (large herbivore) & & 1968 & \\
\hline 16 & Perforated tooth (Cervus elaphus) & & & \\
\hline 17 & Perforated tooth (Cervus elaphus) & & & \\
\hline 18 & Perforated tooth (Cervus elaphus) & & 1967, Cas.I, 5.60-5.80 m, 600 & hearth nearby \\
\hline 19 & Perforated tooth (Cervus elaphus) & & 1968 & \\
\hline 20 & Perforated tooth (Cervus elaphus) & & 1967, Cas.I, 5.60-5.80 m, 600 & hearth nearby \\
\hline 21 & Perforated tooth (Cervus elaphus) & & 1968 & \\
\hline 22 & Perforated tooth (Cervus elaphus) & & & \\
\hline 2 & 11 perforated gastropod shells & \multirow[t]{7}{*}{ Epi II } & 1965, S.V, sq.1, 2.88-2.91 m, 353 & hearth nearby \\
\hline 3 & 2 perforated gastropod shells & & 1967, Int. A, 3.73-3.83 m, 386 & hearth nearby \\
\hline 5 & Bone pendant & & 1965, S.V, sq.1, 3.85 m, 344 & \\
\hline 6 & Perforated tooth (Cervus elaphus) & & \multirow{3}{*}{$\begin{array}{l}\text { one of them is from 1966, Cas.D, } \\
3.53-3.70 \mathrm{~m}, 424\end{array}$} & \\
\hline 7 & Perforated tooth (Cervus elaphus) & & & \\
\hline 8 & Perforated tooth (Cervus elaphus) & & & \\
\hline 9 & Perforated fish vertebra (Silurus glanis) & & $\begin{array}{l}\text { possibly 1967, Cas.I, 3.90-4.00 } \\
\text { m, } 592\end{array}$ & \\
\hline 23 & Antalis bead & \multirow[t]{2}{*}{ Criș III } & 1968, Int.B & hearth nearby \\
\hline 24 & Stone disc (ring) & & 1969, Cas.S, 0.53 m, 698 & \\
\hline 25 & Bone belt fragment & \multirow[t]{6}{*}{ Criș II } & $\begin{array}{l}\text { 1968, Cas.K, } 1.25-1.35 \mathrm{~m} \text { or } \\
\text { 1965, S.IV, sq.2, 2.02-2.22 m, } 92 \\
\text { or 1965, S.V, sq.2A, } 2.30-2.45 \mathrm{~m}, \\
287\end{array}$ & $\begin{array}{l}\text { hearths nearby } \\
\text { in S.IV and S.V }\end{array}$ \\
\hline 26 & Perforated Silurus glanis vertebra & & 1966, Cas.H, $2.20 \mathrm{~m}$ & \\
\hline 27 & Perforated canine (Vulpes vulpes) & & 1966, Cas.E, $2.60 \mathrm{~m}$ & \\
\hline 28 & Perforated Unio shell & & 1969, Cas.S, $0.70 \mathrm{~m}, 700$ & \\
\hline 29 & Perforated Unio shell & & 1969, Cas.S, $0.84 \mathrm{~m}, 702$ & \\
\hline 30 & Stone belt element & & & \\
\hline 31 & Bone bead & \multirow[t]{2}{*}{ Criș I } & 1967, Cas.I, $2.60 \mathrm{~m}$ & hearth nearby \\
\hline 32 & Bone belt fragment & & $\begin{array}{l}\text { 1965, S.V, sq.2B, 2.34-3.56 m, } \\
320\end{array}$ & hearth nearby \\
\hline
\end{tabular}


Table 5. Categories of adornments in the existing collection from Cuina Turcului.

\begin{tabular}{|c|c|c|c|c|}
\hline \multirow[b]{2}{*}{$\begin{array}{c}\text { Raw } \\
\text { material }\end{array}$} & \multirow[b]{2}{*}{ Species } & \multirow[b]{2}{*}{ Typology } & \multirow{2}{*}{\begin{tabular}{|c|} 
Mesolithic \\
No. of pieces
\end{tabular}} & Early Neolithic \\
\hline & & & & No. of pieces \\
\hline \multirow{8}{*}{ shell } & Lithoglyphus naticoides & bead & 37 & 1 \\
\hline & Lithoglyphus apertus & bead & 3 & - \\
\hline & Tritia sp. & bead & 3 & - \\
\hline & Theodoxus danubialis & bead & 8 & 1 \\
\hline & Zebrina detrita & bead & 1 & - \\
\hline & Columbella sp. & bead & - & 1 \\
\hline & Antalis sp. & tubular bead & 1 & 1 \\
\hline & Unio sp. & pendant? & - & 2 \\
\hline \multirow{7}{*}{ tooth } & Cervus elaphus & pendant & 11 & - \\
\hline & Sus scrofa & pendant & 1 & - \\
\hline & Canis lupus & pendant & 1 & - \\
\hline & Vulpes vulpes & pendant & - & 1 \\
\hline & herbivore & pendant & 1 & - \\
\hline & Castor fiber & pendant & 1 & - \\
\hline & $?$ & pendant & 1 & - \\
\hline \multirow{3}{*}{ bone } & Silurus glanis & pendant & 1 & 1 \\
\hline & \multirow{2}{*}{$?$} & pendant & 1 & - \\
\hline & & cylindrical bead & - & 2 \\
\hline antler & Cervus elaphus & pendant & 1 & - \\
\hline \multirow{2}{*}{ stone } & \multirow{2}{*}{$?$} & disc bead & - & 1 \\
\hline & & belt element & - & 1 \\
\hline
\end{tabular}

remarked were "identical" to the cylindrical and barrel-shaped beads from Hoard I at Lepenski Vir ${ }^{40}$, though he made no specific comment on the raw material composition of the beads. Since these 16 beads are not part of the existing collection in the "Vasile Pârvan" Institute of Archaeology, we cannot confirm the presence or absence of Spondylus shell among them. According to Păunescu's field notes (p.16-17), the 16 beads and three perforated gastropod shells were found in S.V, sq.1, 1.65-1.80 m, while another cylindrical bead was found in S.V, sq.1, 1.58-1.63 m (Tab. 2). The field notes also mention for this same area a large number of pottery sherds, many from large vessels, a grinding stone, two stone axes, a bone awl, 145 flaked lithic artefacts and abundant faunal remains comprising gastropod and bivalve shells, Canis and beaver teeth, and bird bones.

There are clear parallels for the non-shell adornments from Cuina Turcului at other sites in the Iron Gates region. Pendants of mammalian teeth (red deer and fox) were found in the "EpipalAeolithic" layers at Climente II Cave. The perforated rectangular bone pendant from the Epi II horizon at Cuina Turcului has parallels in two similar pieces found at Vlasac ${ }^{41}$. Stone rings and disc beads are known from Early Neolithic contexts at Lepenski Vir ${ }^{42}$ and Schela Cladovei $^{43}$, while an analogue for the stone "belt buckle" from Cuina Turcului was also noted at Lepenski Vir ${ }^{44}$.

\footnotetext{
40 Păunescu 1978, 33.

41 Srejović, Letica 1978, Pl CVI/4.6.

42 Srejović 1969, Fig.82; Borić 2016, Fig. 4.67.

43 Unpublished data.

44 Srejović 1969, Fig.12; Srejović 1969a, Fig. VI.10, 12.
} 


\section{The broader picture}

Perforated gastropod shells, tusk shells, mammalian teeth, and bone and antler pendants are widespread in Upper Palaeolithic and Mesolithic contexts throughout Southeast Europe ${ }^{45}$. However, the distribution of such adornments in the Early Neolithic is much more restricted geographically. They have been found in Starčevo-Criș settlements within the Iron Gates and in parts of the Lower Danube catchment beyond. Perforated shells of freshwater gastropods and perforated mammal teeth occurred at Măgura-Buduiasca (southern Romania) ${ }^{46}$, while in northern Serbia perforated teeth were found at Drenovac and tusk shell beads at Starčevo ${ }^{47}$.

Innovations also occur, both on the typological and technological level. An apparently novel element in the Early Neolithic of Cuina Turcului is the perforated bivalves of Unio sp., which have also been found in Early Neolithic contexts elsewhere in the Iron Gates - at Schela Cladovei ${ }^{48}$ and Pojejena-Nucet ${ }^{49}$. Outside the Iron Gates these occur either in the form of shells perforated by the same indirect percussion technique, as at Tărtăria-Pietroșița ${ }^{50}$ and Măgura-Buduiasca ${ }^{51}$, or by a more complex manufacturing process also observed at Măgura-Buduiasca. Another novel element of the Early Neolithic at Cuina Turcului is the appearance of disc beads ${ }^{52}$, rings, belt elements and "buttons" made of bone or stone, examples of which occur elsewhere in the Iron Gates at Alibeg ${ }^{53}$, Schela Cladovei ${ }^{54}$, Lepenski Vir ${ }^{55}$ and Vlasac ${ }^{56}$ in Early Neolithic or transitional Mesolithic-Neolithic contexts.

These new ornament types represent a tradition that originated in the Near East and spread through Southeast Europe with the first farmers ${ }^{57}$. Their co-occurrence in the Iron Gates with perforated gastropod shells and mammal tooth pendants suggests a fusion of Mesolithic and Neolithic traditions consequent upon the arrival and integration into the region of a new population with different cultural practices, mirrored also in the human archaeogenetic record ${ }^{58}$.

\section{Acknowledgements}

MM and AB's work was supported by a grant of Ministry of Research and Innovation, CNCS - UEFISCDI, project number PN-III-P1-1.1-TE-2016-0182, within PNCDI III and by a research grant developed with the financial support of the Recurring Donors Fund at the disposal of the Romanian Academy and managed by the "PATRIMONIU" Foundation GAR-UM-2019-II-2.1-1 (project no. GAR-UM-2019-II-2.1-1/15.10.2019).

\section{REFERENCES}

Bărbat, Mărgărit, Barbu 2020

Beldiman 2004
Bărbat, I. Al., Mărgărit, M., Barbu, M.G., The first farmers adornments from an Early Neolithic settlement discovered at Tărtăria - Pietroșița (Alba County, Romania), Mărgărit, M., Boroneanţ, A. (eds.), Beauty and the eye of the beholder: personal adornments across the millennia, Editura Cetatea de Scaun: Târgoviște, 2020, 269-288.

Beldiman, C., Parures préhistoriques de Roumanie: dents percées paléolithiques et épipaléolithiques (25 000-10 000 BP), Memoria Antiquitatis, 23, 2004, 69-102.

\footnotetext{
${ }^{45}$ Borić, Cristiani 2019.

46 Beldiman, Sztancs 2009; Mărgărit, Mirea, Radu 2018.

47 Vitezović 2012.

48 Pickard, Boroneant, Bonsall 2017.

49 Luca 1995; Beldiman, Sztancs 2013.

${ }^{50}$ Bărbat, Mărgărit, Barbu 2020.

${ }^{51}$ Beldiman, Sztancs 2009; Mărgărit, Mirea, Radu 2018.

52 Variously referred to in the literature as disc, flat or annular beads.

${ }^{53}$ Boroneanţ, Mărgărit, Bonsall 2019.

${ }^{54}$ Bonsall et al. 2011; Boroneanț, McSweeney, Bonsall 2014; Boroneanț, Mărgărit, Bonsall 2019.

55 Srejović 1969; Borić 2016.

${ }^{56}$ Borić et al. 2014.

${ }^{57}$ Disc beads and related forms are known from Early Neolithic sites in Bulgaria (e.g. Galabnik, Kovačevo), Serbia (e.g. Baštine, Bubanj, Divostin, Donja Branjevina, Golokut, Grivac, Starčevo), southeast Hungary (e.g. Ecsegfálva), and southern Romania (e.g. Măgura-Buduiasca): McPherron, Rasson, Galdikas 1988; Starnini, Szakmány, Whittle 2007; Beldiman, Sztancs 2009; Sidéra 2012; Vitezović 2012; Gurova, Bonsall 2017; Boroneanț, Mărgărit, Bonsall 2019.

${ }^{58}$ González Fortes et al. 2018; Mathieson et al. 2019.
} 
Beldiman, Sztancs 2009

Beldiman, Sztancs 2013

Bonnardin 2009

Bonsall, Boroneanț 2018

Bonsall et al. 2011

Borić 2016

Borić, Cristiani 2019

Borić et al. 2014

Boroneanț 1970

Boroneanț 2000

Boroneant 2011

Boroneanț 2012

Boroneanț, Bălășescu 2016

Boroneanț, Bonsall 2016

Boroneanț, McSweeney, Bonsall 2014

Boroneanț, Mărgărit, Bonsall 2019

Cristiani, Borić 2012
Beldiman, C., Sztancs D.-M., Industria materiilor dure animale aparţinând culturii Starčevo-Criş descoperită în aşezarea de la Măgura "Buduiasca - Boldul lui Moş Ivănuş", jud. Teleorman. Consideraţii asupra repertoriului tipologic, Buletinul Muzeului Judeţean Teleorman. Seria Arheologie, 1, 2009, 31-54.

Beldiman, C., Sztancs, D.-M., The osseous artefacts of the Starčevo-Criș culture in Romania. An overview, Comșa, A., Bonsall, C., Nikolova, L. (eds.), Facets of the Past. The Challenge of the Balkan Neo-Eneolithic. Proceedings of the International Symposium Celebrating the $85^{\text {th }}$ Birth Anniversary of Eugen Comşa, 6-12 october 2008, Editura Academiei Române: București, 2013, 106-133.

Bonnardin S., La parure funéraire au Néolithique ancien dans les Bassins parisien et rhénan Rubané, Hinkelstein et Villeneuve-Saint-Germain, Societé Préhistorique Française, Mémoire 49, Paris, 2009.

Bonsall, C., Boroneanţ, A., The Iron Gates Mesolithic: a brief review of recent developments, L'Anthropologie, 122, 2018, 264-280.

Bonsall, C., Boroneanț, A., Boroneanț, V., Dobrescu, R., Pătroi, N.C., Schela CladoveiLa Canton (km. 935), Cronica Cercetărilor Arheologice din România. Campania 2011. http://cronica.cimec.ro/detaliu.asp?k=4709\&d=Drobeta-Turnu-Severin-MehedintiSchela-Cladovei--La-Canton-km-935, accessed: 12 December 2019.

Borić, D., Deathways at Lepenski Vir. Patterns in Mortuary Practice: Excavations of Dragoslav Srejović, Serbian Archaeology Society, Belgrade, 2016.

Borić, D., Cristiani, E., Taking beads seriously: prehistoric forager ornamental traditions in Southeastern Europe, PaleoAnthropology, 2019, 208-239.

Borić, D., French, C.A.I., Stefanović, S., Dimitrijević, V., Cristiani, E., Gurova, M., Antonović, D., Allué, E.A., Filipović. D., Late Mesolithic lifeways and deathways at Vlasac (Serbia), Journal of Field Archaeology, 39(1), 2014, 4-31.

Boroneant, V., La période epipaléolithique sur la rive roumaine des Portes de Fer du Danube, Praehistorische Zeitschrift, XLV, 1970, 1-25.

Boroneant, V., Paléolithique supérieur et Épipaléolithique dans la zone des Portes de Fer, Editura Silex: Bucureşti, 2000.

Boroneanț, A., The Mesolithic in Banat, Draşovean, F., Jovanović, B. (eds), The prehistory of Banat. I: the Palaeolithic and Mesolithic, Romanian Academy: Bucharest, 2011, 103-141.

Boroneant, A., Aspecte ale tranziției de la mezolitic la neoliticul timpuriu în zona Porțile de Fier, Bibliotheca Historica et Archaeologica, Banatica, 52, Cluj-Napoca, 2012.

Boroneant, A., Bălășescu, A., Materialul faunistic din nivelurile neolitice timpurii din adăpostul sub stâncă de la Cuina Turcului, In Memoriam Alexandra Bolomey, Materiale şi Cercetări Arheologice, 12, 2016, 27-44.

Boroneant, A., Bonsall, C., The Icoana burials in context, Grünberg. J.M., Gramsch, B., Larsson, L., Orschiedt, J., Meller, H. (eds), Mesolithic burials-rites, symbols and social organisation of early postglacial communities, vol. II, Landesmuseum für Vorgeschichte Halle (Saale): Halle, 2016, 757-780.

Boroneant, A., McSweeney, K., Bonsall, C., Schela Cladovei 1982 - A supplement to the original excavation report of Vasile Boroneanț, Analele Banatului, S.N., XXII, 2014, 17-31.

Boroneanț, A., Mărgărit, M., Bonsall, C., Discoidal beads: Novel elements of the Starcevo Early Neolithic package, Sîrbu, V., Comșa, A., Hortopan, D. (eds.), Digging in the Past of Old Europe, Studies in Honour of Cristian Schuster at his $60^{\text {th }}$ Anniversary, Editura Istros a Muzeului Brăilei „Carol I”: Tg. Jiu - Brăila, 2019, 51-72.

Cristiani, E., Borić, D., 8500-year-old Late Mesolithic garment embroidery from Vlasac (Serbia): technological, use-wear and residue analyses, Journal Archaeological Science, 39, 2012, 3450-3489. 
Cristiani, Živaljević, Borić 2014

Falci et al. 2019

Grossu 1970

Gurova, Bonsall 2017

Lazăr, Mărgărit, Radu 2018

Lenneis 2007

Mărgărit 2008

Mărgărit 2016

Mărgărit, Dimache 2019

Mărgărit, Mirea, Radu 2018

Mărgărit et al. 2018

McPherron, Rasson, Galdikas 1988

Nicolăescu-Plopșor et al. 1968

Păunescu 1970

Păunescu 1978

Păunescu 2000

Pickard, Boroneant, Bonsall 2017

Rigaud 2011
Cristiani E., Živaljević I., Borić D., Residue analysis and ornament suspension techniques in prehistory: cyprinid pharyngeal teeth beads from Late Mesolithic burials at Vlasac (Serbia), Journal of Archaeological Science, 46, 2014, 292-310.

Falci, C.G., Cuisin, J., Delpuech, A. van Gijn, A., Hofman, L.C., New insights into use-wear development in bodily ornaments through the study of ethnographic collections, Journal of Archaeological Method and Theory, 26, 2019, 755-805.

Grossu, Al.V. Anexa nr. V, Unele observații asupra gasteropodelor descoperite în straturile Romanello-Aziliene de la Cuina Turcului, Păunescu, Al., Epipaleoliticul de le Cuina Turcului-Dubova, Studii şi Cercetări de Istorie Veche, 21(1), 1970, 45.

Gurova, M., Bonsall, C., Experimental replication of stone, bone, and shell beads from Early Neolithic sites in Southeast Europe, in Bar-Yosef Mayer, D.E., Bonsall, C., Choyke, A. (eds.), Not Just for Show. The Archaeology of Beads, Beadwork, \& Personal Ornaments, Oxbow Books: Oxford, 2017, 159-167.

Lazăr, C., Mărgărit, M., Radu, V., Evidence for the production and use of Lithoglyphus naticoides beads in Europe during the Holocene: The case of Sultana-Malu Roșu site (Romania), Quaternary International, 472, 2018, 84-96.

Lenneis, E., Mesolithic heritage in Early Neolithic burial rituals and personal adornments, Documenta Praehistorica, 34, 2007, 129-137.

Mărgărit, M., L'art mobilier paléolithique et mésolithique de Roumanie et de la République Moldova, en contexte central et est-européen, Editura Cetatea de Scaun: Târgovişte, 2008.

Mărgărit, M., Testing the endurance of prehistoric adornments: Raw materials from the aquatic environment, Journal of Archaeological Science, 70, 2016, 66-81.

Mărgărit, M., Dimache, M. Personal adornments from the Eneolithic necropolis of Chirnogi-Șuvița Iorgulescu (Romania): a picture of symbolism in prehistoric communities, Documenta Praehistorica, 46, 2019, 398-413.

Mărgărit, M., Mirea, P., Radu, V., Exploitation of aquatic resources for adornment and tool processing at Măgura "Buduiasca" ("Boldul lui Moș Ivănuș") Neolithic settlement (southern Romania), Quaternary International, 472, 2018, 49-59.

Mărgărit, M., Radu, V., Boroneant,, A., Bonsall, C., Experimental studies of personal ornaments from the Iron Gates Mesolithic, Archaeological and Anthropological Sciences, 10(8), 2018, 2095-2122.

McPherron, A., Rasson, J., Galdikas, B., Other artifact categories, McPherron, A., Srejović, D. (eds.), Divostin and the Neolithic of Central Serbia, University of Pittsburgh: Pittsburgh, 1988, 325-343.

Nicolăescu-Plopşor, C.S., Bujor E., Boroneanţ, V., Comșa, E., Constantinescu, N., Diaconu, P., Morintza, S., Păunescu, Al., Popilian, G., Roman, P., Rezultatele arheologice din zona Porților de Fier, Comunicări, Seria Arheologică, IV, Craiova, 1968, 3-58.

Păunescu, Al., Epipaleoliticul de le Cuina Turcului-Dubova, Studii și Cercetări de Istorie Veche, 21(1), 1970, 3-47.

Păunescu, Al., Cercetări arheologice de la Cuina Turcului-Dubova (jud. Mehedinți), Tibiscus, 1978, 11-56.

Păunescu, Al., Paleoliticul şi Mezoliticul din spaţial cuprins între Carpaţi şi Dunăre, Editura AGIR: București, 2000.

Pickard, C., Boroneanț, A., Bonsall, C., Molluscan remains from Early to Middle Holocene sites in the Iron Gates reach of the Danube, Southeast Europe, in Allen M.J. (ed.), Molluscs in Archaeology: methods, approaches and applications, Oxbow Books: Oxford, 2017, 179-194.

Rigaud, S., La parure: traceur de la géographie culturelle et des dynamiques de peuplement au passage Mésolithique-Néolithique en Europe (Unpublished $\mathrm{PhD}$ Thesis), Université Bordeaux 1, Bordeaux, 2011. 
Rigaud 2013

Rigaud, d'Errico, Vanhaeren 2015

Sidéra 2012

Srejović 1969

Srejović, Letica 1978

Stanković 1986

Starnini, Szakmány, Whittle 2007

Sztancs et al. 2016

Tiță 2007

Vanhaeren, d'Errico 2001

Vanhaeren et al. 2013

Vitezović 2012
Rigaud S., Les objets de parure associés au dépôt funéraire mésolithique de Große Ofnet: implications pour la compréhension de l'organisation sociale des dernières sociétés de chasseurs-cueilleurs du Jura Souabe, Anthropozoologica, 48(2), 2013, 207-230.

Rigaud S., d'Errico F., Vanhaeren, M., Ornaments reveal resistance of North European cultures to the spread of farming, PLoS ONE, 10(4), e0121166, doi:10.1371/journal.pone.0121166.

Sidéra, I., Nouveau regard sur la néolithisation. L'industrie osseuse de l'Anatolie au Bassin parisien via la Méditerranée, De Boccard: Paris, 2012.

Srejović, D., Lepenski Vir: nova praistorijska kultura u Podunavlju, Srpska Knjizevna Zadruga, Beograd, 1969.

Srejović, D., Letica, Z., Vlasac. A Mesolithic Settlement in the Iron Gates, Serbian Academy of Sciences and Arts: Beograd, 1978.

Stanković, S., Localité Knjepište - une station du groupe de Starčevo, Đerdapske sveske, 3, 1986, 447-452.

Starnini, E., Szakmány, G., Whittle, A., Polished, ground and other stone artefacts, in Whittle, A. (ed.), The Early Neolithic of the Great Hungarian Plain. Investigations of the Körös culture site of Ecsegfalva 23, County Bekes, volume II, Varia Archaeologica Hungarica XXI, Institute of Archaeology, Hungarian Academy of Sciences: Budapest, 2007, 667-676.

Sztancs, D.-M., Beldiman, C., Barbu, M.Gh., Barbu, M.M., Artefacts made of perforated shells discovered in a Bronze Age ritual pit from Uroi, Hunedoara County, Romania, in Vitezovic, S. (ed.), Close to the Bone: Current Studies in Bone Technologies, Institute of Archaeology: Belgrade, 2016, 338-355.

Tiță, R., Comments on the Badenian fauna (Middle Miocene) from Bahna (Southern Carpathians, Romania), Travaux du Museum National d'Histoire Naturelle "Grigore Antipa", 50, 2007, 543-550.

Vanhaeren, M., d'Errico, Fr., Le mobilier funéraire de la Dame de Saint-Germain-laRivière (Gironde) et l'origine paléolithique des inégalités, Paléo, 15, 2003, 195-238.

Vanhaeren, M., d'Errico, F., van Niekerk, K.L., Henshilwood, C.S., Erasmus, R.M., Thinking strings: additional evidence for personal ornament use in the Middle Stone Age at Blombos Cave, South Africa, Journal of Human Evolution, 64, 2013, 500-517.

Vitezović, S., The white beauty - Starčevo culture jewellery, Documenta Praehistorica, 39, 2012, 215-226.

\section{LISTA ILUSTRAṬIILOR}

Figura 1. Situri din mezoliticul și neoliticul timpuriu de la Porțile de Fier, menționate în text; 2. planul general al adăpostului sub stâncă de la Cuina Turcului, cu indicarea secțiunilor din care au fost prelevate probe ${ }^{14} \mathrm{C}$.

Figura 2. Secvența stratigrafică a secțiunilor S.II, S.III și Cas. M, cu indicarea straturilor din care au fost prelevate probe ${ }^{14} \mathrm{C}$.

Figura 3. Cochilii perforate de Lithoglyphus naticoides (mezolitic) (scara $=1 \mathrm{~cm}) ; 2 .-3$. detalii ale perforației $(50 \mathrm{x}$, 75x); 4.-5. deformări ale aperturii (50x, 50x); 6.-7. uzură la nivelul apexului (100x, 150x); 8. cochilii perforate de Lithoglyphus apertus (mezolitic); 9. detaliu perforație (50x); 10.-11. stigmate de abraziune (100x, 100x).

Figura 4. 1. Cochilii perforate de Thedoxus danubialis (mezolitic) (scara $=1 \mathrm{~cm}) ; 2$. detaliu perforație (50x); 3. deformarea perforației (100x); 4. deformarea aperturii (50x); 5. cochilii perforate de Tritia neritea (mezolitic) $($ scara $=1 \mathrm{~cm}) ; 6 .-7$. detalii ale perforației $(50 x, 50 x) ; 8$. deformarea perforației $(100 x)$; 9. cochilie perforată de Zebrina detrita (mezolitic) $(\mathrm{scara}=1 \mathrm{~cm}) ; 10$. detaliu perforație $(50 \mathrm{x}) ; 11$. cochilie de Antalis sp. (mezolitic) (scara $=1 \mathrm{~cm}) ; 12$. detaliu al extremității $(50 \mathrm{x})$. 
Figura 5. 1-8. Dinți perforați de Cervus elaphus (mezolitic) (scara = $1 \mathrm{~cm}) ; 2$. stigmate de raclage $(50 \mathrm{x}) ; 3 .-4,9$. detalii ale perforației $(30 x, 50 x, 20 x) ; 5 .-6 ., 10$. urme de uzură la nivelul perforației (100x, 100x, 50x); 7., 11. urme de uzură la nivelul coroanei $(100 x, 100 x)$.

Figura 6. 1. Incisiv inferior de mistreț perforat (mezolitic) (scara $=1 \mathrm{~cm}) ; 2 ., 5$ detalii ale perforației $(50 x, 50 x) ; 3$. urme de uzură la nivelul perforației (150x); 4. incisiv de lup perforat (mezolitic) (scara $=1 \mathrm{~cm}) ; 6$. incisiv de erbivor perforat $($ mezolitic $)(\mathrm{scara}=1 \mathrm{~cm}) ; 7$. incisiv de castor perforat $($ mezolitic $)(\mathrm{scara}=1 \mathrm{~cm}) ; 8$. dinte perforat, specie indeterminabilă (mezolitic) $($ scara $=1 \mathrm{~cm})$; 9. stigmate de tăiere $(100 \mathrm{x}) ; 10 .-12$. detalii ale perforației $(50 \mathrm{x}, 50 \mathrm{x}, 75 \mathrm{x})$.

Figura 7. 1. Pandantiv din os (mezolitic) $(\mathrm{scara}=1 \mathrm{~cm}) ; 2$. stigmate de tăiere $(50 \mathrm{x}) ; 3 ., 7$. stigmate de raclage $(35 \mathrm{x}$, $30 x)$; 4., 8., 13. detalii ale perforației $(35 \mathrm{x}, 30 \mathrm{x}, 30 \mathrm{x})$; 5. urme de ocru $(150 \mathrm{x})$; 6. pandantiv din corn (mezolitic) $($ scara $=1 \mathrm{~cm})$; 9.-10. detalii ale decorului $(20 \mathrm{x}, 150 \mathrm{x}) ; 11$. vertebre de pește perforate (mezolitic și neolitic timpuriu) $($ scara $=1 \mathrm{~cm}) ; 12$. detaliu contur $(30 \mathrm{x})$.

Figura 8. 1. Cochilie perforată de Lithoglyphus naticoides (neolitic timpuriu) (scara $=1 \mathrm{~cm}) ; 2 ., 5$., 8. detalii ale perforației $(50 \mathrm{x}, 50 \mathrm{x}, 50 \mathrm{x}) ; 3 ., 6$. deformarea aperturii $(50 \mathrm{x}, 50 \mathrm{x}) ; 4$. cochilie perforată de Thedoxus danubialis (neolitic timpuriu) $($ scara $=1 \mathrm{~cm}) ; 7$. cochilie perforată de Columbella $\mathrm{sp}$. (neolitic timpuriu) $(\mathrm{scara}=1 \mathrm{~cm}) ; 9 ., 11$. uzură la nivel de perforație (150x, 150x); 10. uzură la nivelul apexului (200x); 12. cochilie de Antalis sp. (neolitic timpuriu) (scara = $1 \mathrm{~cm})$; 13.-14. deformarea extremității $(100 x, 50 x) ; 15$. fațetă aplatizată $(100 x)$.

Figura 9. 1. Valve perforate de Unio sp. (neolitic timpuriu) (scara $=1 \mathrm{~cm}) ; 2 .-4$. detalii ale perforației $(50 \mathrm{x}$, $30 x, 100 x)$; 5. perforație nefinalizată $(25 x) ; 6$. canin perforat de Vulpes vulpes (neolitic timpuriu) $($ scara $=$ $1 \mathrm{~cm}) ; 7 ., 11$. detalii ale perforației $(50 x, 100 x)$; 8. uzură la nivelul perforației $(100 x)$; 9. mărgele din os (neolitic timpuriu) $($ scara $=1 \mathrm{~cm}) ; 10$. detaliu contur $(100 x) ; 12$. stigmate de tăiere $(100 x) ; 13$. stigmate de tăiere şi abraziune (100x).

Figura 10. 1. Disc din piatră (neolitic timpuriu) (scara $=1 \mathrm{~cm}) ; 2$. detaliu contur $(35 \mathrm{x}) ; 3 ., 10$. detalii ale perforației $(50 x ; 50 x) ; 4$. urme de ocru $(150 x)$; 5. element de centură (neolitic timpuriu) (scara $=1 \mathrm{~cm}) ; 6 .-7$. stigmate de abraziune (50x; 50x); 8.-9. stigmate de tăiere (50x).

Tabelul 1. Date ${ }^{14} \mathrm{C}$ din nivelurile neolitice timpurii din adăpostul sub stâncă de la Cuina Turcului (după Bonsall, Boroneanț 2018). Intervalele de vârstă calibrate sunt rotunjite cu 10 ani.

Tabelul 2. Podoabe menționate în documentaţia de teren (categoriile tipologice sunt preluat din caietele de teren).

Tabelul 3. Artefacte publicate versus artefacte înregistrate în caietele de teren (*indică prezența artefactelor, fără a avea un număr specificat). Categoriile de artefacte urmează descrierile din publicații/caietele de teren.

Tabelul 4. Contextele arheologice ale podoabelor din colecția provenind de la Cuina Turcului, pe baza informațiilor scrise pe artefact corelate cu informațiile din notițele de teren.

Tabelul 5. Categoriile de podoabe provenind de la Cuina Turcului conservate la Institutul de Arheologie „Vasile Pârvan" din București.

MONICA MĂRGĂRIT,

"Valahia" University of Târgoviște, Department of History, 34-36 Lt. Stancu Ion St, Târgoviște, Romania; "Vasile Pârvan" Institute of Archaeology, Romanian Academy,

11 Henri Coandă St, Bucharest, Romania, monicamargarit@yahoo.com

ADINA BORONEANT,

"Vasile Pârvan" Institute of Archaeology, Romanian Academy,

11 Henri Coandă St, Bucharest, Romania, boro30@gmail.com

CLIVE BONSALL,

University of Edinburgh, School of History, Classics and Archaeology, William Robertson Wing, Old Medical School, Teviot Place, Edinburgh EH8 9AG, United Kingdom, clive.bonsall@ed.ac.uk 